\title{
Tumor-B-Cell Interactions Promote Isotype Switching to an Immunosuppressive IgG4 Antibody Response Through Upregulation of IL-10 in Triple Negative Breast Cancers
}

Nicole J. Toney

University of Delaware

Lynn M. Opdenaker

ChristianaCare: Christiana Care Health Services Inc

Kader Cicek

University of Delaware

Holly Archinal

ChristianaCare: Christiana Care Health Services Inc

Lisa Frerichs

Christiana Care Health Services: Christiana Care Health Services Inc

Christopher Ryan Kennington

University of Delaware

Samuel Oberly

ChristianaCare: Christiana Care Health Services Inc

Rajasekharan Somasundaram

Wistar Institute

Jennifer Sims-Mourtada ( $\boldsymbol{}_{\text {jsimsmourtada@christianacare.org })}$

Christiana Care Health Services: Christiana Care Health Services Inc https://orcid.org/0000-0003-16024560

Research article

Keywords: Breast cancer, Triple negative breast cancer, IgG4, B cells, Interleukin 10

Posted Date: October 11th, 2021

DOl: https://doi.org/10.21203/rs.3.rs-956230/v1

License: (c) (i) This work is licensed under a Creative Commons Attribution 4.0 International License.

Read Full License 

Tumor-B-cell interactions promote isotype switching to an immunosuppressive IgG4 antibody response through upregulation of IL-10 in Triple Negative breast cancers

Nicole J Toney ${ }^{1,2}$, Lynn Opdenaker ${ }^{1}$ Kader Cicek $^{12}$ Holly Archinal $^{1}$, Lisa Frerichs ${ }^{1}$, Christopher Ryan Kennington ${ }^{3}$, Samuel Oberly ${ }^{1}$, Rajasekharan Somasundaram ${ }^{3}$, Jennifer Sims-Mourtada ${ }^{1,2,3}$

${ }^{1}$ Cawley Center for Translational Cancer Research, Helen F Graham Cancer Center and Research Institute, Christiana Care Health Services, Inc. Newark, USA

${ }^{2}$ Department of Biological Sciences, The University of Delaware, Newark, DE, USA

${ }^{3}$ The Wistar Institute, Philadelphia, Pennsylvania, USA

Keywords: Breast cancer; Triple negative breast cancer; IgG4; B cells; Interleukin 10

Correspondence: Jennifer Sims-Mourtada, PhD

Center for Translational Cancer Research

Helen F. Graham Cancer Center and Research Institute Christiana Care Health Services, Inc. 4701 Ogletown Stanton Rd Suite 4300

Newark, Delaware 19713

Tel 1- 302-623-4648

Fax 1-302- $623-4314$

Email jsimsmourtada@christianacare.org 


\section{Abstract}

Background: Triple negative breast cancer (TNBC) is an aggressive breast cancer for which there is currently no targeted therapy. Tumor-infiltrating B-cells (TIB) have been observed in tumor tissues of TNBC patients, but their functional role is unclear. IgG4 is one of four antibody subclasses of $\lg G$ expressed and secreted by B cells. Unlike other IgG isotypes, IgG4 has an immunosuppressive function and is induced by Th2-type cytokines. In cancers such as melanoma, IgG4 has been linked with advanced disease and poor patient survival. Therefore, we sought to determine the role of $\lg G 4$ in TNBC.

Methods: We performed co-culture assays to examine expression of Th2 cytokines by TNBC cells with and without the presence of B cells. We also performed in vitro class switching experiments with peripheral B cells with and without co-culture with TNBC cells in the presence or absence of an IL-10 blocking antibody. We examined expression of CD20+ TIB, IgG4 and Th2 cytokines by immunohistochemistry in 152 TNBC samples. Statistical analysis was done using Log-Rank and Cox-proportional hazards tests.

Results: Our findings indicate that B cells interact with TNBC to drive chronic inflammatory responses through increased expression of inflammatory cytokines including the TH2 cytokines IL-4 and IL-10. In vitro class switching studies show that interactions between TNBC cell lines and $B$ cells drive isotype switching to the IgG4 isotype in an IL-10 dependent manner. In patient tissues, expression of IgG4 correlates with CD20 and tumor expression of IL-10. Both IgG4 and tumor IL-10 are associated to shorter recurrence free survival (RFS) and overall survival (OS) in TNBC. In a multi-variant analysis, IL-10 was associated with poor outcomes indicating that tumor $\mathrm{IL}-10$ may drive immune escape.

Conclusions: These findings indicate that interactions between TIB and TNBC results in activation of chronic inflammatory signals that suppress antibody driven immune responses 


\section{Background:}

Triple negative breast cancer (TNBC) accounts for approximately $15 \%$ of all breast cancers and is defined by lack of expression of estrogen and progesterone receptors, and lack of overexpression of human epidermal growth factor receptor 2 (HER2). TNBC is an aggressive breast cancer subtype characteristic of having quick progression and poor patient outcomes. Patients have higher rates of early recurrence than other breast cancer subtypes, particularly in the first 5 years after diagnosis ${ }^{1}$. Due to the aggressive nature of TNBC, patients tend to have poor prognosis, including poor overall survival (OS), breast-cancer specific survival (BCSS), and recurrence-free survival (RFS) ${ }^{1-3}$. It is unclear what drives the aggressive nature of TNBC.

While genetics may play a role, the tumor microenvironment has a substantial influence on many tumor attributes. An inflammatory tumor microenvironment is often present in TNBC. Compared to other breast cancer subtypes, TNBC has a higher level of tumor infiltrating lymphocytes, including CD8 and CD4+ T cells, and CD20+ B cells ${ }^{4-6}$. Likewise, expression of inflammatory cytokines, immunosuppressive genes and markers of chronic inflammation are higher in TNBC than other breast cancer subtypes ${ }^{4-8}$. Although high densities of infiltrating lymphocytes are associated to increased response to chemotherapy and better outcomes in highly proliferative tumors, this prognostic association may be lost in tumors with lower proliferative capacity and in certain subtypes of TNBC, such as the claudin low subtype ${ }^{6,9}$. Additionally, gene signatures related to chronic inflammatory responses have been associated to ER negativity, increased metastasis and poor prognosis in TNBC 4, 8, 10,11. Moreover, increased activation of NfKB, STAT3 and AP-1 pathways has been observed in triple negative cell lines and tumors compared to other breast cancer subtypes ${ }^{11}$.

Chronic inflammation associated with the humoral immune response has been found to promote aggressiveness in a number of solid tumor types. B lymphocytes have been shown to drive chronic inflammation in a murine model of inflammation-associated epithelial cancer, contributing 
to tumor-promoting processes such as an angiogenesis, epithelial cell proliferation, and further recruitment of immune cells ${ }^{12}$. B lymphocyte-derived factors have also been shown to upregulate proteins and transcription factors involved in pro-inflammatory signaling pathways such as IKK complex proteins and STAT3 in tumor cells, resulting in tumor-promoting processes such as inflammation and angiogenesis ${ }^{13-18}$. Moreover, TIB cells were found to induce chronic inflammation in melanoma, leading to activation of the inflammatory NfKB signaling pathway ${ }^{19}$.

Chronic inflammation is known to induce immunosuppressive responses in both malignant and non-malignant tissues through a variety of process affecting both innate and adaptive immunity. Immune modulation of antibody responses occurs in part through class switching to the immunosuppressive IgG4 antibody subtype. This switch is driven by chronic antigen exposure and T-helper type 2 cytokines such as IL-4and IL-10 10, 20-22 and serves to ramp down the immune system during inflammatory responses 23,24 . Due to the unique structure of its hinge region, IgG4 has reduced effector functions compared to other lgG isotypes. These structural changes result in poor ability to bind complement and Fc receptors and to activate effector cells ${ }^{23}$. Furthermore, IgG4 can interact with other antibodies of the $\lg G$ (particularly $\lg G 1$ ) and $\lg E$ classes through their Fc domains, serving in an immunoregulatory role to decrease antibody responses ${ }^{25-27}$.

The presence of $\lg \mathrm{G} 4$ antibodies has been reported in a subset of cancer types, namely melanoma ${ }^{28-30}$, extrahepatic cholangiocarcinoma ${ }^{31}$, glioblastoma ${ }^{32}$, pancreatic cancer ${ }^{33}$, and hepatocellular carcinoma ${ }^{34}$ and has been shown to have a negative correlation with recurrence free and overall survival $29,30,34$. Although the role of IgG4 in breast cancer is unclear, a recent study reported an enrichment of $\lg \mathrm{G}+$ clonally expanded B cells in TNBC, with an increase in IgG4 class switching in TNBC compared to non-TNBC ${ }^{35}$. In this study we sought to understand the mechanisms driving IgG4 class switching in TNBC and determine the relationship of IgG4+ B cells in the TME to patient outcomes. 


\section{Methods}

\section{$\underline{\text { Cell culture and reagents }}$}

MDA-MB-231 cells obtained from American Type Culture Collection were maintained in RPMI1640 medium (ThermoFisher Scientific, \#11875) + 10\% FBS (ThermoFisher Scientific, \#10437028) and 1\% antibiotic/antimycotic (ThermoFisher Scientific, \#15240). SUM159 cells were obtained from Asterand (Detroit, MI) and cultured in Ham's F12 medium (ThermoFisher Scientific, \#11765) + 10\% FBS, 1x antibiotic/antimycotic, 2 ug/ml insulin (ThermoFisher Scientific, \#12585) and $100 \mathrm{ng} / \mathrm{ml}$ hydrocortisone (Sigma-Aldrich, \#H0135). Primary human peripheral B lymphocytes and EBV transformed B cells were grown in RPMI-1640 + CellXVivo Human B Cell Expansion Kit as described by manufacturer (R\&D Systems, \#CDK005), L-glutamine (ThermoFisher Scientific, \#25030), 2-mercaptoethanol (ThermoFisher Scientific, \#21985), Insulin, Penicillin-Streptomycin (ThermoFisher Scientific, \#15070063), and 10\% FBS. EBV-transformed human peripheral B cells were grown in RPMI $+10 \%$ FBS and $1 \mathrm{x}$ antibiotic/antimycotic and treated with CellXVivo Human B cell expansion kit for experimental analysis. .

\section{Isolation of PBMCs and Flow Cytometry}

Peripheral human blood was obtained with consent from women with TNBC prior to surgical resection or treatment and peripheral blood mononuclear cells (PBMCs) were isolated using Ficoll-Paque ${ }^{\circledR}$ (GE Healthcare, \#95021). B lymphocytes were isolated using B Cell Isolation Kit II, human (Miltenyi Biotech, \#130-091-151) according to the manufacturer's instructions. For cocultures, B cells and tumor cells were separated with a 0.4 um 6-well cell culture insert with B cells in the upper chamber. Cells were cultured for 6 days, with media changed on day 3. Following co-culture, B cells were prepared for flow cytometry analysis by staining with an IgG4 antibody for 30 minutes in the dark (\#9200-09, mouse anti-human IgG4 PE-conjugated, 1:50, SouthernBiotech). Cells were washed, resuspended in $300 \mathrm{ul} \mathrm{PBS}+10 \%$ FBS, and filtered 
through a 35-um filter cap in a $5 \mathrm{ml}$ FACS tubes to create a single cell suspension. Samples were run on the BD FACSAria II (BD Biosciences) at the Christiana Care's Helen F. Graham Cancer Center and Research Institute core facility. For IL-10 blocking studies, anti-human IL-10 (clone JES3-97D, Biolegend) was added at a concentration of $1 \mathrm{ug} / \mathrm{ml}$, daily during co-culture.

\section{$\underline{\text { Real-Time PCR }}$}

Tumor cell lines were cultured with and without B cells for 24 hours as described above and RNA was isolated. Real-time PCR was performed as previously described ${ }^{36}$. Samples were run on an Applied Biosystems' 7500 Fast Real-Time PCR System with Power SYBR Green PCR Master Mix (Life Technologies), using the primers described in Table 1.

\section{ELISA}

For the IL-10 ELISA, tumor cells were co-cultured with B cells for 24-hours. Control cells were incubated with media only. To ensure detection of tumor cell IL-10, B lymphocytes and media were removed, and fresh media was added back to wells for a 24-hour period. Supernatants were then collected, spun down to remove cell debris, and analyzed using the Quantikine IL-10 Elisa kit (R\&D systems) according to manufacturer's instructions. For the IgG4 Elisa, EBV B cells were activated and co-cultured with or without TNBC cell lines for 5 days as previously described. B cells were then removed and allowed to expand for two weeks. Cells were then plated for 24 hours and supernatant was captured. Supernatants were analyzed using the Human IgG4 Elisa kit (Invitrogen). Absorbance was read at 450nm on the Infinite® 200 PRO NanoQuant (Tecan Life Sciences).

\section{$\underline{\text { Patient samples }}$}


Breast cancer tissue specimens were obtained from the Helen F. Graham Cancer Center and Research Institute (HFGCCRI) biorepository under a protocol approved by the institutional review board. Tissue was obtained from surgical resection from women diagnosed with TNBC who consented to the use of their tissues for research. Tissue blocks were prepared by formalinfixation and paraffin-embedding. Tissues were constructed into $4 \times 5$ tissue microarrays (TMA) with a $5 \mathrm{~mm}$ core size and cut as serial sections.

$\underline{\text { Immunohistochemical procedure }}$

Serial paraffin-embedded slides were deparaffinized and rehydrated, and heat antigen epitope retrieval was performed for 16 hours at $60^{\circ} \mathrm{C}$. Slides were stained using the DAB Substrate kit (Abcam, ab64238) for IL-10 and CD20 and the Mouse and Rabbit Specific HRP/AEC (ABC) Detection IHC Kit (Abcam, ab93705) for IL-4 and IgG4, following the manufacturer's instructions. Primary antibodies were incubated overnight at $4^{\circ} \mathrm{C}$ with a rabbit monoclonal antibody to $\operatorname{lgG} 4$ (Abcam, ab109493, 1:1000), a rabbit polyclonal antibody to IL-4 (Abcam, ab9622, 1:100), and mouse monoclonal antibodies to CD20 (Abcam, ab9475, 1:100) and IL-10 (Santa Cruz, sc-8438, 1:50). Slides were counterstained with Harris hematoxylin for 10 minutes. Images were captured using a Zeiss Axio microscope using a 10X objective. CD20 was scored by overlaying a 20x20 grid of $1 \mathrm{~mm}$ squares and calculating the percent of tissue-containing squares which contained 10+ lymphocytes. IgG4 was scored by counting the total number of IgG4+ B cells. For IL-10 and IL-4 staining, segmentation of tumor cells and measurement of integrated density was performed using Zen Blue. The median intensity or percentage was used to determine low vs high samples. For CD20, low, intermediate and high density was determined using the mean+/- one standard deviation.

\section{Statistical analysis}


Statistical analysis was done in graph pad PRISM 8 and IBM27 SPSS. Relationships among scored slides was done using Spearman's correlation analysis. Flow cytometry and real time quantitative PCR data was analyzed using student's T-test. Survival and recurrence were analyzed using Kaplan-Meier curves and Mantel Log-Rank tests. Multi-variate analysis was carried out using Cox-proportional hazards tests.

Results

\section{$B$ cells induce chronic inflammation in TNBC}

Chronic inflammation is a hallmark of TNBC. ${ }^{11}$ TIB cells have been associated with chronic inflammatory signatures ${ }^{15-18,37}$ and have been shown to secrete several inflammatory cytokines in breast cancer ${ }^{38}$. While previous studies have shown that tumor cells are capable of activating inflammatory signaling cascades in B cells ${ }^{35,38}$, the effects of this interaction on tumor cells are less clear. We therefore sought to determine the effects of B cells on tumor cells in co-culture studies with primary peripheral B cells isolated from the blood of TNBC patients. We observed increases in gene expression of several inflammatory cytokines in TNBC cells co-cultured with B cells (Figure 1a). Of particular interest was upregulation of the TH2 type cytokines IL-10 and IL-4 in triple negative cells, which have been shown to drive lgG4 expression and are associated with immunosuppressive responses 22,39 . To confirm these findings, we conducted a 24-hour co-culture of primary human peripheral B cells isolated from women with TNBC and the TNBC cell lines MDA-MB-231 and SUM159. Real-time PCR was used to analyze changes in gene expression of IL-10 and IL-4. We found significant increases in IL-10 gene expression in both cell lines (Figure 1b). An average 7.5-fold increase was observed in SUM159 and a 7.4-fold increase was observed in MDA-MB-231 cells co-cultured with B cells compared to controls. Increases in gene expression of IL-4 was also observed in both lines, 3.4-fold increase for SUM159 and 2.1-fold increase for MDA-MB-231, but this increase was only significant in the SUM159 cell line. To determine if this gene expression correlated to an increase in protein expression, we performed an ELISA specific 
for human IL-10. To determine tumor-specific production of IL-10, TNBC cell lines were cocultured for 24 hours with B cells, followed by a 24 hour culture without B cells, after which media was removed and analyzed for the presence of IL-10 protein. As shown in Figure 1c, there was a significant increase in secreted IL-10 protein in tumor cells co-cocultured with B cells. These findings indicate that cross-talk between tumor cells and B cells promotes inflammatory signaling in tumor cells that may be associated with immunosuppression.

\section{TNBC Cells Enhance IgG4 Expression by B Lymphocytes}

IL-10 expression is often present at sites of chronic inflammation and promotes immunosuppression of humoral responses through induction of isotype switching to $\lg G 4$. Therefore, we sought to determine if TNBC could alter the isotype profile of B cells. We performed an in vitro assay to determine if IgG4 class switching is differentially induced upon activation of B cells co-cultured with TNBC cell lines compared to controls. Co -culture of both MDA-MB-231 cells and SUM159 with primary peripheral B cells isolated from TNBC patients resulted in significant increases of IgG4+ cells, suggesting increased IgG4 class switching in response to TNBC cell co-culture (figure $2 a$ and b). To confirm IgG4 class switching, an IgG4 specific ELISA assay was performed in EBV-transformed B cells co-cultured with tumor cells. Significantly higher levels of IgG4 were observed in B cell supernatants two weeks after co-culture with TNBC cell lines (Figure 2c). Likewise, EBV B cells were shown to undergo in vitro isotype switching similar to peripheral B cells upon co-culture with TNBC cell lines in flow cytometry experiments (Figure 2d and e). To examine the role of IL-10 in class switching, we examined class switching in EBVtransformed B cells upon co-culture with TNBC with and without the addition of an IL-10 blocking antibody. As shown in Figure $2 \mathrm{~d}$ and e, the addition of the anti-IL10 antibody significantly blocked IgG4 class switching in co-cultured cells. These findings indicate that TNBC can induce IgG4 class switching in B cells in an IL-10 dependent manner. 


\section{Presence of IgG4+ B cells, IL-10 and IL-4 in the tumor microenvironment of TNBC}

To investigate the presence of IgG4 and inflammatory cytokines in TNBC, we sought to evaluate protein expression by immunostaining tumor specimens from 150 triple negative tumors. Table 2 provides a summary of clinical data and patient characteristics. In order to quantify lgG4+B cell and total $B$ cell infiltration in TNBC tissues, serial sections of tissue microarrays were stained by immunohistochemistry for the pan-B cell marker CD20, IgG4, IL-10 and IL-4 (Figure 3). The majority of tumors contained CD20+ B cells. Only 5 sections (3.3\%) scored negative for CD20+ B cells. The average density of B cells was $30.1 \%$. A low density of B cells was defined to be those tumors less than one standard deviation from the mean, while high density was defined as a B cell density more than one standard deviation above the mean. Twenty tumors (13.3\%) had low density, $93(62 \%)$ had intermediate density and $27(18 \%)$ had high density. IgG4+ cells were more often found in tumors with low or intermediate B cells (Figure 4, $\mathrm{p}=.002$ ). Tumor cell IL-10 staining was detected in 68 (45\%) patients with high expression observed in 42 patients. Tumor cell IL-4 staining was detected in 102 tumors (68\%), with high expression observed in 75 patients.

\section{IgG4+B cells correlate with IL-10 expression, higher stage and poor outcomes}

Prior studies indicate that IL-4 and IL-10 polarize IgG4 class switching ${ }^{30}$, and that IgG4+ B cells are increased in advanced cancer ${ }^{28}$, and associate with poor patient survival ${ }^{29,30}$ and increased recurrence ${ }^{34}$. Therefore, we compared immunohistochemically stained markers and clinicopathological characteristics using Spearman's correlation analysis (Table 3). We observed no correlation of $\mathrm{CD} 20+\mathrm{B}$ cell infiltration and stage or grade. Interestingly, a weak negative correlation was found between IgG4 and CD20+B cells density $(r=-0.190, p=.021)$ as well as stage and $B$ cell density $(-0.199, p=0.021)$ confirming previous findings that a high $B$ cell density is associated with better prognosis ${ }^{38}$. A correlation was also observed between IgG4 staining and tumor expressed IL-10 ( $r=0.0 .488, p=0.000)$, and IL-4 $(r=0.262, p=0.001)$, as well as between IL10 and tumor stage (IL-10 $r=0.254, p=0.016)$. 
To assess the effects of IgG4+ B cells on patient outcomes, Kaplan-Meyer analysis was performed. Consistent with previous studies, high B cell density was found to have significantly better RFS $(p=0.033)$ and OS $(p=0.010)$ than intermediate or low B cell density (Figure $5 a)$. Patients with high IgG4+ cells had significantly worse RFS $(p=0.000)$ and OS $(p=0.000)$ (Figure 5b). Furthermore, high tumor expression of IL-10 and IL-4 resulted in lower recurrence free survival ( $p=0.000$ for IL-10; $p=0.021$ for IL-4) (Figures $5 c$ and $d$ ). While high IL-10 expression resulted in worse OS $(=0.000)$, high expression of IL-4 had no significant effect on OS $(p=0.137)$. In a multi-variant analysis, IgG4 positivity $(\mathrm{p}=0.001 ; \mathrm{HR}=3.366 ; 95 \% \mathrm{Cl} 1.607-7.050)$, tumor IL-10 $(p=0.000 ; H R=7.195 ; 95 \% \mathrm{Cl} 2.418-21.411)$ and tumor stage and tumor stage $(p=0.000$; $H R=1.442 ; 95 \% \mathrm{Cl} 1.0247-1.667$ ) were independently associated with a shorter RFS. However, only tumor stage $(p=0.000 ; H R=1.329 ; 95 \% \mathrm{Cl} 1.151-1.534)$ and IL-10 $(p=0.005 ; H R=4.1401$; $95 \% \mathrm{Cl} 1.538-10.934)$ were independently associated with a shorter OS (Table 4).

\section{Discussion}

In this study, we report that presence of IgG4+ B cells in the tumor microenvironment of TNBC associates with increased tumor recurrence and poor patient survival. We also report that presence of $\operatorname{lgG} 4+\mathrm{B}$ cells correlates with tumor expression of IL-10 and trends with expression of IL-4 by tumors. As IL-10 and IL-4 are known to promote class switching to IgG4 ${ }^{22,39}$, these findings indicate that TNBC may create a tumor microenvironment that supports class switching to the $\lg G 4$ subtype.

TIB have been shown to undergo class switching and somatic hypermutation at a higher frequency in TNBC than other breast cancer subtypes ${ }^{40,41}$. Although an increase in IgG1 has been associated with better prognosis ${ }^{41}$, the role of $\lg G 4$ has is unclear in breast cancer. However, the association between IgG4 and poor outcomes has been demonstrated in melanoma 
and other tumor types $24,28,29$. Consistent with our findings, these studies have also shown TIB expressing IgG4 correlate with the presence of Th2 cytokines ${ }^{29}$.

Based on our studies, it is yet to be determined if IgG4 in TNBC actively contributes to poor patient outcomes, or if it is a bystander in a larger process. There is evidence in melanoma that IgG4 hinders tumor associated antigen targeted $\lg G 1$, regardless of if the $\lg G 4$ antibody was antigen specific or not, indicating that IgG4 may actively impede an anti-tumor antibody response regardless of antigen specificity ${ }^{31}$. In addition to promoting IgG4 class switching, IL-10 is an immunosuppressive cytokine, and can inhibit the ability of dendritic cells and macrophages to activate CD4+ helper T cells ${ }^{42}$. In breast cancer, IL-10 expression in tumors positively correlates with locally advanced disease, higher tumor grade, and hormone-receptor negativity ${ }^{43}$. This finding is different in non-TNBC, where IL-10 is found to be a good prognostic indicator of diseasefree survival (DFS) ${ }^{44}$. In melanoma, IL-10 expression by tumor cells associates with melanoma progression ${ }^{4531}$, and high serum IL-10 associates significantly with worse $\mathrm{OS}^{46}$. Therefore, it is possible that IL-10 expression by tumor cells may also be a driver of poor outcomes in TNBC, and this may be independent of lgG4+ B cells. This is supported by our multi-variant analysis where only stage and tumor IL-10 were predictive of shorter OS. Although not examined in the scope of this study, significant expression of IL-10 was also observed in TIB and may play a role in directing anti-tumor immune responses as well.

In this study, we find that B cells enhance inflammatory responses, including IL-10 expression in TNBC cells. Cross-talk between tumor cells and TIB may help to shift the immune response towards and immunosuppressive state through induction of IL-10 expression and release by tumor cells. Enhanced IL-10 expression has also been reported in melanoma cells co-cultured with $\mathrm{B}$ cells. ${ }^{30}$ The mechanism driving IL-10 gene expression in tumor cells is not yet fully understood. Gene expression studies show that the transcription factors AP-1 and NFKB are 
important in driving transcription of $\mathrm{IL}-10$, but the majority of studies have been conducted in immune cells ${ }^{47}$. Further study is needed to determine if IL-10 expression by TNBC is dependent upon B cell induced NFKB or other inflammatory signaling mechanisms. Understanding what drives IL-10 expression in TNBC may reveal potential therapeutic targets for TNBC.

The ability of tumor cells to direct TIB behavior has been previously described in melanoma and lung cancer ${ }^{48,49}$. Co-culture with supernatants of melanoma cells was able to induce activation of NFKB and expression of inflammatory cytokines in B cells as well as isotype switching to lgG4. Likewise, co-culture of LPS-stimulated lung tumor cells was shown to induce IL-10 expression and a regulatory phenotype in peripheral B cells. However, these studies did not investigate effects on tumor cells. Our studies show that that co-culture also results in increased expression of inflammatory cytokines by tumor cells. Our findings indicate that significant cross-talk may occur between B cells and tumor cells that may help to shape immune responses. Whether or not enhanced inflammatory signaling in TNBC occurs as a direct consequence of B cell expressed inflammatory cytokine expression remains to be determined.

The role of humoral immune responses in breast cancer is unclear. Recently, high densities of TIB were found to associate with good prognosis in breast cancer ${ }^{38}$. Garaud et al., reported TIB cells with a germinal center phenotype $\left(\mathrm{CD} 19^{+} \mathrm{CD} 38^{\mathrm{high}} \lg \mathrm{D}^{-}\right)$were more often found in breast cancers with high TIB density and these cells were found to associate with tertiary lymphoid structures and maintain functionality. Analysis of secreted immunoglobulins in the supernatants of TIB showed increases in $\lg G 1$, $\lg G 2$ and $\lg G 3$ with increasing TIB density, with a higher concentration of $\lg A$ obtained from tissues with intermediate B cell infiltration ${ }^{38}$. Likewise, increased clonal expansion of lgG+ cells has been reported in stromal clusters ${ }^{35}$. These findings indicate that TIB isotype may be associated with B cell density or other features of the tumor microenvironment. In our study, IgG4 expression was associated with low to medium density of TIB. Of note, IgG4 expressing B cells were more often located intratumorally and diffusely spread 
throughout the tumor microenvironment, as opposed to being located in B cell aggregates or at the invasive margin. This spatial distribution may promote more interactions with tumor cells as opposed to other immune cells as has been previously described ${ }^{50}$. The association to tertiary lymphoid structures was not examined in our study and it is unknown if these structures are needed for isotype switching to IgG4 or if this polarization occurs elsewhere. Furthermore, the exact phenotype and clonality of $\lg 4^{+} \mathrm{B}$ cells remains to be characterized.

\section{Conclusions}

Our results support that IgG4 expression by B cells is induced through signaling from TNBC cells, and presence of IgG4+ B cells in the TNBC microenvironment associate with worse patient OS, BCSS, and RFS. We show that infiltration of lgG4+ B cells correlate with intermediate but not high densities of B cell infiltration, IL-10 expression by tumor cells, and higher stage. Understanding the contribution of IgG4+ cells to the immune microenvironment of TNBC may reveal ways in which TIB can contribute to tumor growth and provide new targets to increase the immune response to TNBC.

Ethics approval and consent to participate: All tissues and blood were obtained under a protocol approved by the Internal Review Board (IRB) of ChristianaCare and were obtained from patients who gave consent or under a waiver of consent approved by the IRB.

Consent for publication: Not applicable

Availability of data and materials: The datasets used and/or analyzed during the current study are available from the corresponding author on reasonable request.

Competing interests: The authors declare that they have no competing interests 
Funding: This work was supported by a grant from the Lisa Dean Mosely foundation, and by the Delaware INBRE program, with a grant from the National Institute of General Medical Sciences - NIGMS (P20 GM103446) from the National Institutes of Health and the State of Delaware.

Authors' contributions. N.J.T. made substantial contributions to the design of the work, and the acquisition, analysis and interpretation of data and drafted the work. L.M.O made substantial contributions to the design of the work, and the acquisition, analysis and interpretation of data and drafted the work. K.C. made substantial contributions to the acquisition, analysis and interpretation of data, H.A. made substantial contributions to the acquisition of data, L.F. made substantial contributions to the acquisition of data, C.R.K made substantial contributions to the acquisition of data, S.O. made substantial contributions to the acquisition of data, R.S. made substantial contributions to the design of the work, and the acquisition, analysis and interpretation of data and drafted the work, J.S.M. made substantial contributions to the design of the work, and the acquisition, analysis and interpretation of data and drafted the work.

Acknowledgements: We would like to acknowledge the Flow Cytometry Core Facility in the Cawley Center for Translational Cancer Research. 


\section{References}

1. Lin NU, Vanderplas A, Hughes ME, et al. Clinicopathologic features, patterns of recurrence, and survival among women with triple-negative breast cancer in the National Comprehensive Cancer Network. Cancer. Nov 15 2012;118(22):5463-72. doi:10.1002/cncr.27581

2. Qiu J, Xue X, Hu C, et al. Comparison of Clinicopathological Features and Prognosis in Triple-Negative and Non-Triple Negative Breast Cancer. J Cancer. 2016;7(2):167-73. doi:10.7150/jca.10944jcav07p0167 [pii]

3. Gong Y, Liu YR, Ji P, Hu X, Shao ZM. Impact of molecular subtypes on metastatic breast cancer patients: a SEER population-based study. Sci Rep. Mar 27 2017;7:45411. doi:srep45411 [pii]10.1038/srep45411

4. Liu Z, Li M, Jiang Z, Wang X. A Comprehensive Immunologic Portrait of Triple-Negative Breast Cancer. Transl Oncol. Apr 2018;11(2):311-329. doi:S1936-5233(17)30397-2 [pii]10.1016/j.tranon.2018.01.011

5. Mahmoud SM, Paish EC, Powe DG, et al. Tumor-infiltrating CD8+ lymphocytes predict clinical outcome in breast cancer. J Clin Oncol. May 20 2011;29(15):1949-55. doi:JCO.2010.30.5037 [pii]10.1200/JCO.2010.30.5037

6. Nagalla S, Chou JW, Willingham MC, et al. Interactions between immunity, proliferation and molecular subtype in breast cancer prognosis. Genome Biol. Apr 29 2013;14(4):R34. doi:gb2013-14-4-r34 [pii]10.1186/gb-2013-14-4-r34

7. Bates JP, Derakhshandeh R, Jones L, Webb TJ. Mechanisms of immune evasion in breast cancer. BMC Cancer. May 11 2018;18(1):556. doi:10.1186/s12885-018-4441310.1186/s12885-018-4441-3 [pii] 
8. Liubomirski Y, Lerrer S, Meshel T, et al. Tumor-Stroma-Inflammation Networks Promote Pro-metastatic Chemokines and Aggressiveness Characteristics in Triple-Negative Breast Cancer. Front Immunol. 2019;10:757. doi:10.3389/fimmu.2019.00757

9. Matsumoto $\mathrm{H}$, Thike $\mathrm{AA}, \mathrm{Li} \mathrm{H}$, et al. Increased CD4 and CD8-positive $\mathrm{T}$ cell infiltrate signifies good prognosis in a subset of triple-negative breast cancer. Breast Cancer Res Treat. Apr 2016;156(2):237-47. doi:10.1007/s10549-016-3743-x10.1007/s10549-016-3743-x [pii]

10. Varga EM, Kausar F, Aberer W, et al. Tolerant beekeepers display venom-specific functional IgG4 antibodies in the absence of specific IgE. J Allergy Clin Immunol. May 2013;131(5):1419-21. doi:S0091-6749(12)01452-2 [pii]10.1016/j.jaci.2012.08.037

11. Ji Z, He L, Regev A, Struhl K. Inflammatory regulatory network mediated by the joint action of NF-kB, STAT3, and AP-1 factors is involved in many human cancers. Proc Natl Acad Sci U S A. May 7 2019;116(19):9453-9462. doi:10.1073/pnas.1821068116

12. de Visser KE, Korets LV, Coussens LM. De novo carcinogenesis promoted by chronic inflammation is B lymphocyte dependent. Cancer Cell. May 2005;7(5):411-23. doi:10.1016/j.ccr.2005.04.014

13. Ammirante M, Luo JL, Grivennikov S, Nedospasov S, Karin M. B-cell-derived lymphotoxin promotes castration-resistant prostate cancer. Nature. Mar 11 2010;464(7286):302-5. doi:10.1038/nature08782

14. Martinez-Rodriguez M, Thompson AK, Monteagudo C. A significant percentage of CD20positive TILs correlates with poor prognosis in patients with primary cutaneous malignant melanoma. Histopathology. Nov 2014;65(5):726-8. doi:10.1111/his.12437

15. Garg K, Maurer M, Griss J, et al. Tumor-associated B cells in cutaneous primary melanoma and improved clinical outcome. Hum Pathol. Aug 2016;54:157-64. doi:10.1016/j.humpath.2016.03.022 
16. Meyer S, Fuchs TJ, Bosserhoff AK, et al. A seven-marker signature and clinical outcome in malignant melanoma: a large-scale tissue-microarray study with two independent patient cohorts. PLoS One. 2012;7(6):e38222. doi:10.1371/journal.pone.0038222

17. Huang B, Yang XD, Lamb A, Chen LF. Posttranslational modifications of NF-kappaB: another layer of regulation for NF-kappaB signaling pathway. Cell Signal. Sep 2010;22(9):128290. doi:10.1016/j.cellsig.2010.03.017

18. Yang $\mathrm{C}$, Lee $\mathrm{H}$, Pal S, et al. B cells promote tumor progression via STAT3 regulatedangiogenesis. PLoS One. 2013;8(5):e64159. doi:10.1371/journal.pone.0064159

19. Griss J, Bauer W, Wagner C, et al. B cells sustain inflammation and predict response to immune checkpoint blockade in human melanoma. Nat Commun. Sep 13 2019;10(1):4186. doi:10.1038/s41467-019-12160-2

20. Shamji $\mathrm{MH}$, Ljorring $\mathrm{C}$, Francis $\mathrm{JN}$, et al. Functional rather than immunoreactive levels of IgG4 correlate closely with clinical response to grass pollen immunotherapy. Allergy. Feb 2012;67(2):217-26. doi:10.1111/j.1398-9995.2011.02745.x

21. Agresti A, Vercelli D. Analysis of gamma4 germline transcription in human B cells. Int Arch Allergy Immunol. Feb-Apr 1999;118(2-4):279-81. doi:24099 [pii]10.1159/000024099

22. Jeannin P, Lecoanet S, Delneste Y, Gauchat JF, Bonnefoy JY. IgE versus IgG4 production can be differentially regulated by IL-10. J Immunol. Apr 1 1998;160(7):3555-61.

23. Bruhns $P$, lannascoli $B$, England $P$, et al. Specificity and affinity of human Fcgamma receptors and their polymorphic variants for human IgG subclasses. Blood. Apr 16 2009;113(16):3716-25. doi:10.1182/blood-2008-09-179754

24. Flynn NJ, Somasundaram R, Arnold KM, Sims-Mourtada J. The Multifaceted Roles of B Cells in Solid Tumors: Emerging Treatment Opportunities. Target Oncol. Apr 2017;12(2):139-152. doi:10.1007/s11523-017-0481-x10.1007/s11523-017-0481-x [pii] 
25. Rispens T, Ooievaar-De Heer P, Vermeulen E, Schuurman J, van der Neut Kolfschoten M, Aalberse RC. Human IgG4 binds to IgG4 and conformationally altered IgG1 via Fc-Fc interactions. J Immunol. Apr 1 2009;182(7):4275-81. doi:10.4049/jimmunol.0804338

26. Rispens $\mathrm{T}$, Meesters $\mathrm{J}$, den Bleker TH, et al. Fc-Fc interactions of human IgG4 require dissociation of heavy chains and are formed predominantly by the intra-chain hinge isomer. $\mathrm{Mol}$ Immunol. Jan 2013;53(1-2):35-42. doi:10.1016/j.molimm.2012.06.012

27. Aalberse RC, Stapel SO, Schuurman J, Rispens T. Immunoglobulin G4: an odd antibody. Clin Exp Allergy. Apr 2009;39(4):469-77. doi:10.1111/j.1365-2222.2009.03207.x

28. Daveau M, Pavie-Fischer J, Rivat L, et al. [IgG levels in the sera of melanoma patients (author's transI)]. Ann Dermatol Venereol. Jun-Jul 1977;104(6-7):458-60. Etude des IgG dans les serums des sujets porteurs de melanomes.

29. Karagiannis $\mathrm{P}$, Villanova $\mathrm{F}$, Josephs $\mathrm{DH}$, et al. Elevated IgG4 in patient circulation is associated with the risk of disease progression in melanoma. Oncoimmunology. Nov 2015;4(11):e1032492. doi:10.1080/2162402X.2015.1032492

1032492 [pii]

30. Karagiannis $\mathrm{P}$, Gilbert $\mathrm{AE}$, Josephs $\mathrm{DH}$, et al. IgG4 subclass antibodies impair antitumor immunity in melanoma. J Clin Invest. Apr 2013;123(4):1457-74. doi:65579 [pii]

$10.1172 / \mathrm{JCl} 65579$

31. Harada K, Nakanuma Y. Cholangiocarcinoma with respect to IgG4 Reaction. Int J Hepatol. 2014;2014:803876. doi:10.1155/2014/803876

32. Harshyne LA, Nasca BJ, Kenyon LC, Andrews DW, Hooper DC. Serum exosomes and cytokines promote a T-helper cell type 2 environment in the peripheral blood of glioblastoma patients. Neuro Oncol. Feb 2016;18(2):206-15. doi:nov107 [pii]10.1093/neuonc/nov107 
33. Ngwa T, Law R, Hart P, Smyrk TC, Chari ST. Serum IgG4 elevation in pancreatic cancer: diagnostic and prognostic significance and association with autoimmune pancreatitis. Pancreas. May 2015;44(4):557-60. doi:10.1097/MPA.0000000000000297

34. Wu J, Ma XL, Tian L, et al. Serum IgG4:IgG Ratio Predicts Recurrence of Patients with Hepatocellular Carcinoma after Curative Resection. J Cancer. 2017;8(8):1338-1346. doi:10.7150/jca.18030jcav08p1338 [pii]

35. Harris RJ, Cheung A, Ng JCF, et al. Tumor-Infiltrating B Lymphocyte Profiling Identifies IgG-Biased, Clonally Expanded Prognostic Phenotypes in Triple-Negative Breast Cancer. Cancer Res. Aug 15 2021;81(16):4290-4304. doi:10.1158/0008-5472.CAN-20-3773

36. Arnold KM, Opdenaker LM, Flynn NJ, Appeah DK, Sims-Mourtada J. Radiation induces an inflammatory response that results in STAT3-dependent changes in cellular plasticity and radioresistance of breast cancer stem-like cells. Int J Radiat Biol. Apr 2020;96(4):434-447. doi:10.1080/09553002.2020.1705423

37. de Jonge $\mathrm{K}$, Tille $\mathrm{L}$, Lourenco $\mathrm{J}$, et al. Inflammatory $\mathrm{B}$ cells correlate with failure to checkpoint blockade in melanoma patients. Oncoimmunology. Feb 2 2021;10(1):1873585. doi:10.1080/2162402X.2021.1873585

38. Garaud S, Buisseret L, Solinas C, et al. Tumor infiltrating B-cells signal functional humoral immune responses in breast cancer. JCI Insight. Aug 13 2019;5doi:10.1172/jci.insight.129641

39. Tsuboi H, Matsuo N, lizuka M, et al. Analysis of IgG4 class switch-related molecules in IgG4-related disease. Arthritis Res Ther. Jul 23 2012;14(4):R171. doi:10.1186/ar3924

40. Hu X, Zhang J, Wang J, et al. Landscape of B cell immunity and related immune evasion in human cancers. Nat Genet. Mar 2019;51(3):560-567. doi:10.1038/s41588-018-0339x10.1038/s41588-018-0339-x [pii] 
41. Iglesia MD, Vincent BG, Parker JS, et al. Prognostic B-cell signatures using mRNA-seq in patients with subtype-specific breast and ovarian cancer. Clin Cancer Res. Jul 15 2014;20(14):3818-29. doi:10.1158/1078-0432.CCR-13-3368

42. Mittal SK, Cho KJ, Ishido S, Roche PA. Interleukin 10 (IL-10)-mediated Immunosuppression: MARCH-I INDUCTION REGULATES ANTIGEN PRESENTATION BY MACROPHAGES BUT NOT DENDRITIC CELLS. J Biol Chem. Nov 6 2015;290(45):27158-67. doi:S0021-9258(20)49482-7 [pii]10.1074/jbc.M115.682708

43. Bhattacharjee HK, Bansal VK, Nepal B, Srivastava S, Dinda AK, Misra MC. Is Interleukin 10 (IL10) Expression in Breast Cancer a Marker of Poor Prognosis? Indian J Surg Oncol. Sep 2016;7(3):320-5. doi:10.1007/s13193-016-0512-6

44. Ahmad N, Ammar A, Storr SJ, et al. IL-6 and IL-10 are associated with good prognosis in early stage invasive breast cancer patients. Cancer Immunol Immunother. Apr 2018;67(4):537549. doi:10.1007/s00262-017-2106-8

45. Itakura E, Huang RR, Wen DR, Paul E, Wunsch PH, Cochran AJ. IL-10 expression by primary tumor cells correlates with melanoma progression from radial to vertical growth phase and development of metastatic competence. Mod Pathol. Jun 2011;24(6):801-9. doi:modpathol20115 [pii]10.1038/modpathol.2011.5

46. Zhao S, Wu D, Wu P, Wang Z, Huang J. Serum IL-10 Predicts Worse Outcome in Cancer Patients: A Meta-Analysis. PLoS One. 2015;10(10):e0139598. doi:10.1371/journal.pone. 0139598

PONE-D-15-14839 [pii]

47. Saraiva M, O'Garra A. The regulation of IL-10 production by immune cells. Nat Rev Immunol. Mar 2010;10(3):170-81. doi:nri2711 [pii]

$10.1038 /$ nri2711 
48. Karagiannis $\mathrm{P}$, Fittall M, Karagiannis $\mathrm{SN}$. Evaluating biomarkers in melanoma. Front Oncol. 2014;4:383. doi:10.3389/fonc.2014.00383

49. Zhou J, Min Z, Zhang D, Wang W, Marincola F, Wang X. Enhanced frequency and potential mechanism of B regulatory cells in patients with lung cancer. $J$ Transl Med. Nov 11 2014;12:304. doi:10.1186/s12967-014-0304-0

50. Kinker GS, Vitiello GAF, Ferreira WAS, Chaves AS, Cordeiro de Lima VC, Medina TDS.

B Cell Orchestration of Anti-tumor Immune Responses: A Matter of Cell Localization and Communication. Front Cell Dev Biol. 2021;9:678127. doi:10.3389/fcell.2021.678127 


\section{Figure Legends}

Figure 1 Interactions between TNBC and tumor cells result in upregulation of inflammatory cytokines in tumor cells. (a) Real-time PCR analysis of SUM159 tumor cells co-cultured with B cells showing increases in inflammatory cytokines over non-co-cultured cells. (b) SUM159 tumor cells or MDA-MB-231 cells after 24 hour co-cutlure with B cells result in an increased gene expression of IL-10 and IL-4. Graph shows fold change of co-cultured cells compared to controls. Error bars represent standard deviations. (c) Elisa showing increased protein expression (pg/ml) of IL-10 in SUM159 and MDA-MB-231 cells after co-culture with B cells. This experiment was performed in duplicate. Error bars represent standard deviation of techinical replicants. Significance is indicated by asterisk, ${ }^{* * *} p<.0001,{ }^{* * *} p<.001,{ }^{* *} p<.01,{ }^{*} p<.01$, ns $p>0.05$..

Figure 2. (a\&b). A representative flow cytometry experiement showing increased lgG4+ cells in (a) SUM159 and (b) MDA-MB-231 cells co-cultured with primary peripheral B cells. Graphs show.(c). Graph represents a relative increase in IgG4 protein expression as detected by ELISA in SUM159 and MDA-MB-231 cells co-cultured with B cells compared to control tumor cells. This experiment was performed in duplicate. Error bars represent standard deviation of techinical replicants. (d \&e) A representative flow cytometery dot- plot showing increased IgG4 postitive cells upon co-culture with an EBV-transformed B cell line and (d) SUM159 cells or (e) MDA-MB231 cells. Increase in IgG4 class switching is prevented by addition of an anti-IL-10 antibody during co-cutlure. Graphs show the mean of three independent experiments. Error bars represent standard deviations Significance is indicated by asterisk, ${ }^{* * *} p<.0001,{ }^{* *} p<.001,{ }^{* *} p<.01$, ${ }^{*} p<.01$, ns $p>.05$.

Figure 3. Immunohistochemical analysis of serial tissue sections taken from 4 patients (p1-p4). Tissues were independently stained for for CD20, IgG4, IL-10 and IL-4 (red stain). Nuceli were counterstained with hematoxylin (blue). Images were taken with a 10X objective. 
Figure 4. Quantification of CD20 positive cells in tissue sections by low, meduim and high density. IgG+ cells are represented in black, lgG4- cells are represented in white.

Figure 5. Kaplan Meyer survival curves showing recurrence free and overall survival outcomes for patients with (a) high, intermediate or low densities of CD20, (b) IgG4+ or lgG4- B cells (c) high or low IL-10 expression (d) High or low IL-4 expression. 
Table 1:Primers used for qPCR

$\begin{array}{lll}\frac{\text { Primer }}{\text { VEGF }} & \text { Forward Sequence }\left(5^{\prime}{ }^{\prime} 3^{\prime}\right) & \text { Reverse Sequence }\left(5^{\prime}-3^{\prime}\right) \\ \text { PDGFA } & \text { TGCAGATTATGCGGATCAAACC } & \text { TGCATTCACATTTGTTGTGCTGTAG } \\ \text { PDGFB } & \text { GGTGGTCACAGGTGCTTTTT } & \text { AAACCACTTAAGGCTCTCAGGA } \\ \text { IGF-1 } & \text { TGAGAAAGATCGAGATTGTGCG } & \text { GGGCTTCGGGTCACAGG } \\ \text { IL-1beta } & \text { CATGTCCTCCTCGCATCTCT } & \text { AGCAGCACTCATCCACGATA } \\ \text { IL-4 } & \text { CTGAAAGCTCTCCACCTCCA } & \text { CCAAGGCCACAGGTATTTTG } \\ \text { II-6 } & \text { CACAAGCAGCTGATCCGATTC } & \text { TCTGGTTGGCTTCCTTCACAG } \\ \text { IL-8 } & \text { GACAAAGCCAGAGTCCTTCAGAGA } & \text { CTAGGTTTGCCGAGTAGATCT } \\ \text { IL-10 } & \text { AAGCTGGCCGTGGCTCTCTT } & \text { TGG TGG CGC AGT GTG GTC CA } \\ \text { GAPDH } & \text { GGTTCGCAAGCCTTGTCTGA } & \text { TCCCCCAGGGAGTTCACAT } \\ & \text { CCAGGTGGTCTCCTCTGACTT } & \text { GTGGTCGTTGAGGGCAATG }\end{array}$


Figure 1A

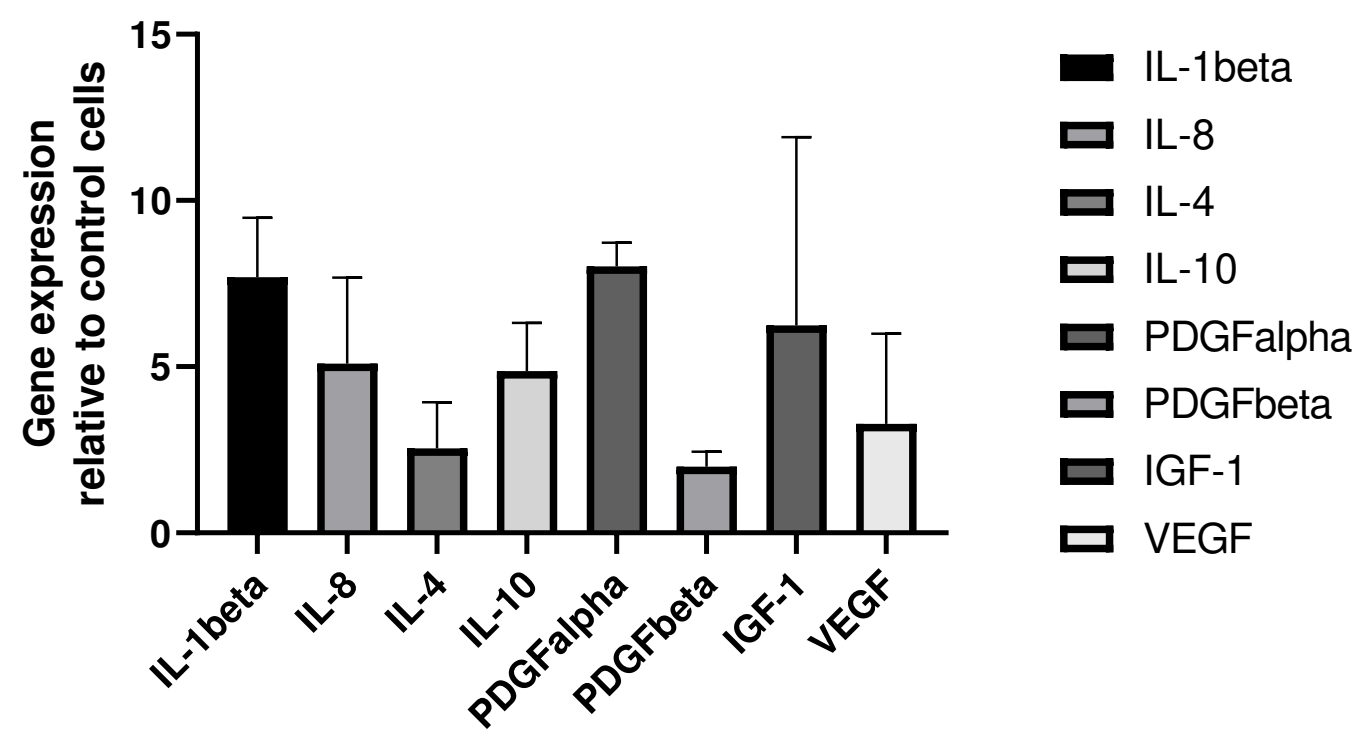


Figure $1 b$
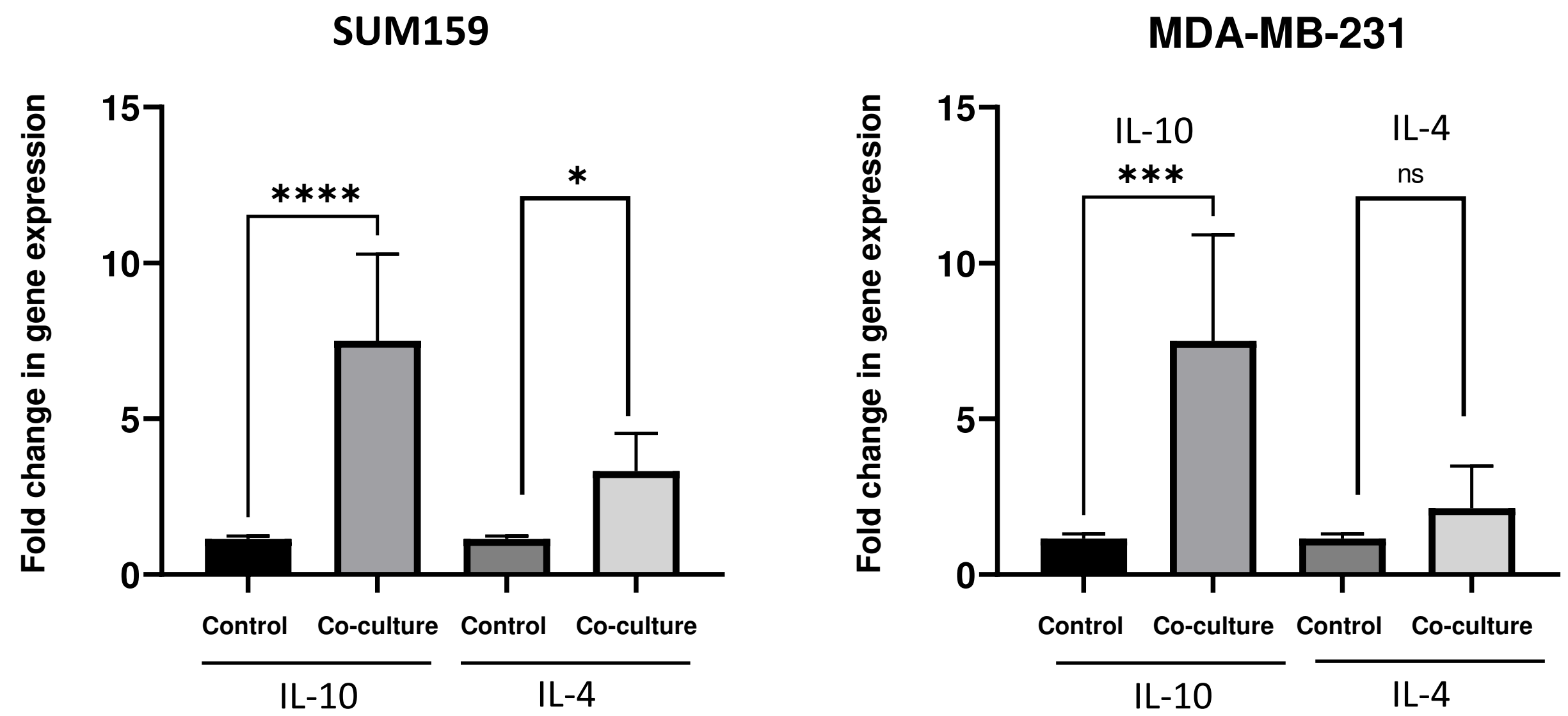
Figure 1c

SUM159

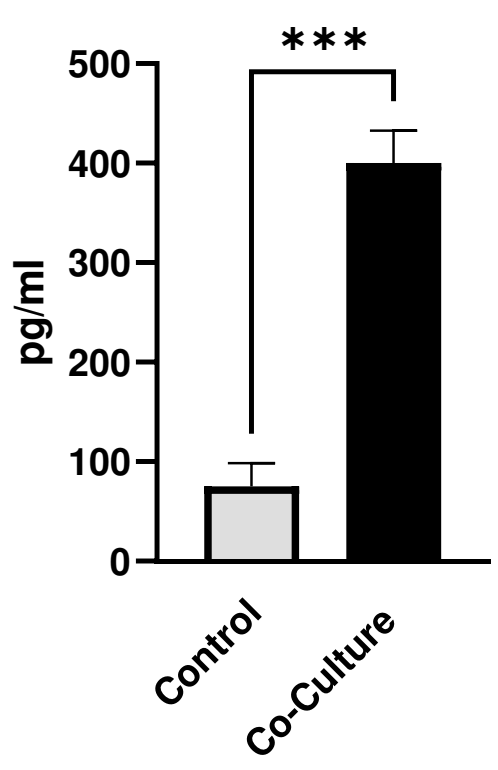

MDA-MB-231

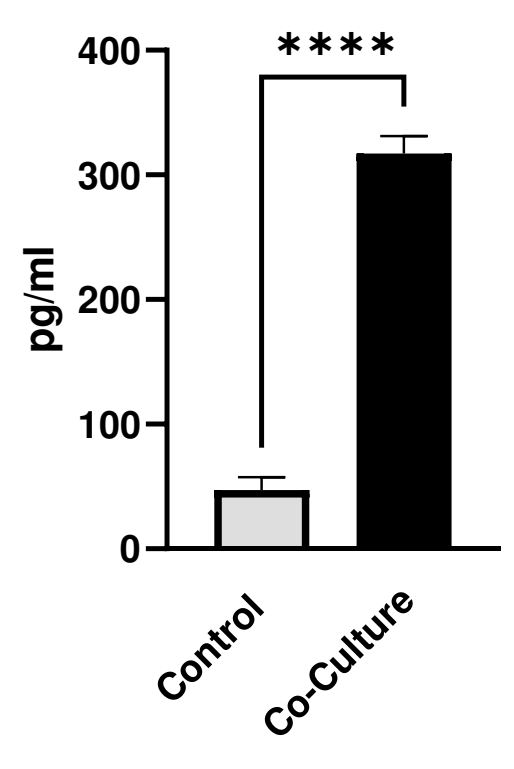


Figure $2 \mathrm{a}$

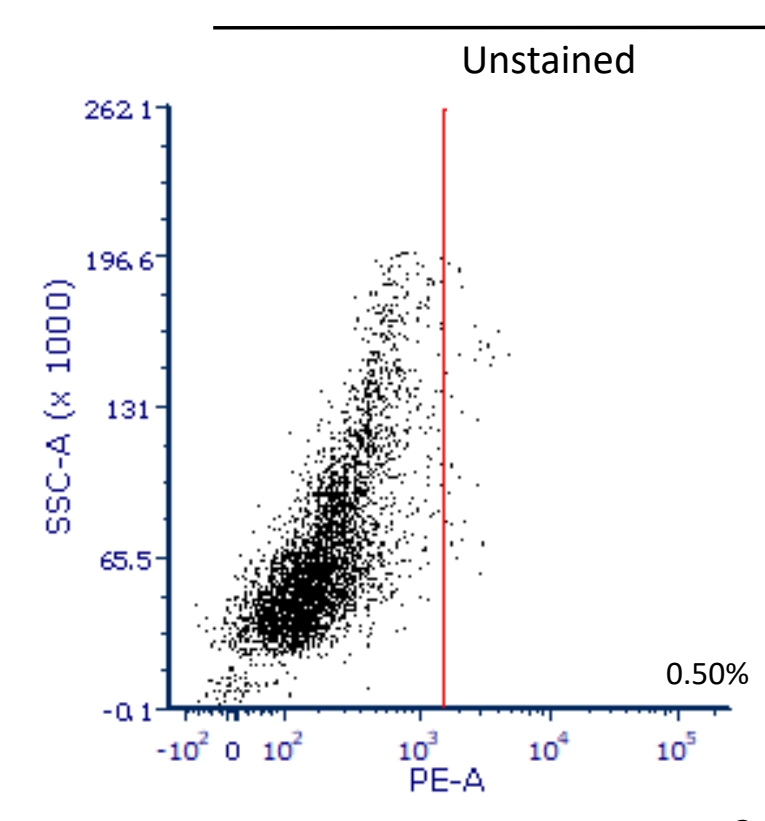

$\frac{0.50 \%}{10^{5}}$

Co-culture

Unstained

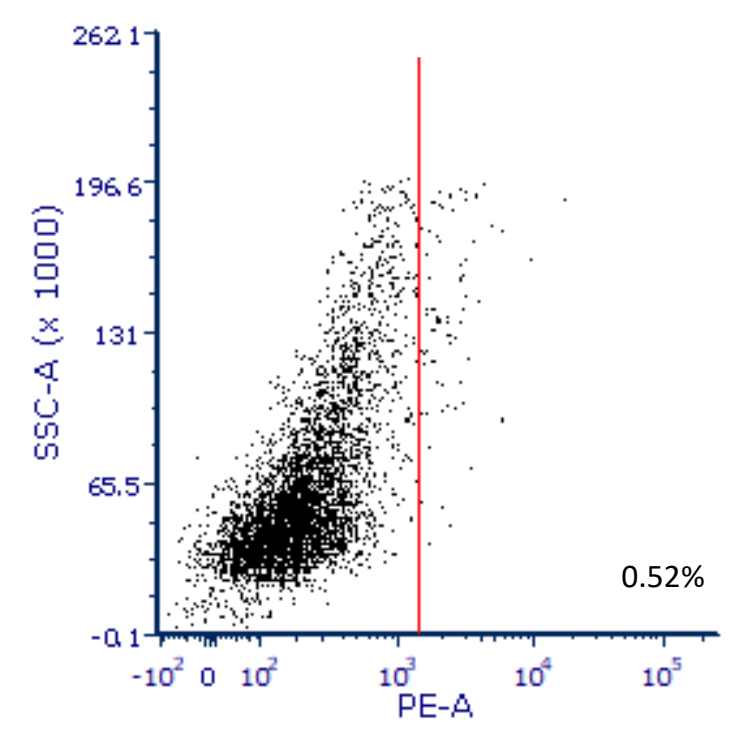

IgG4-PE

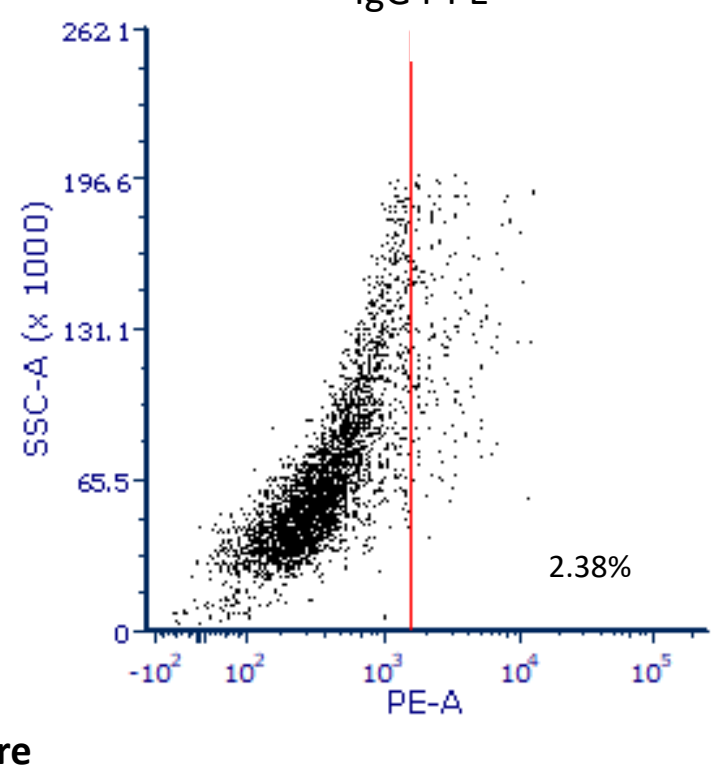

IgG4-PE

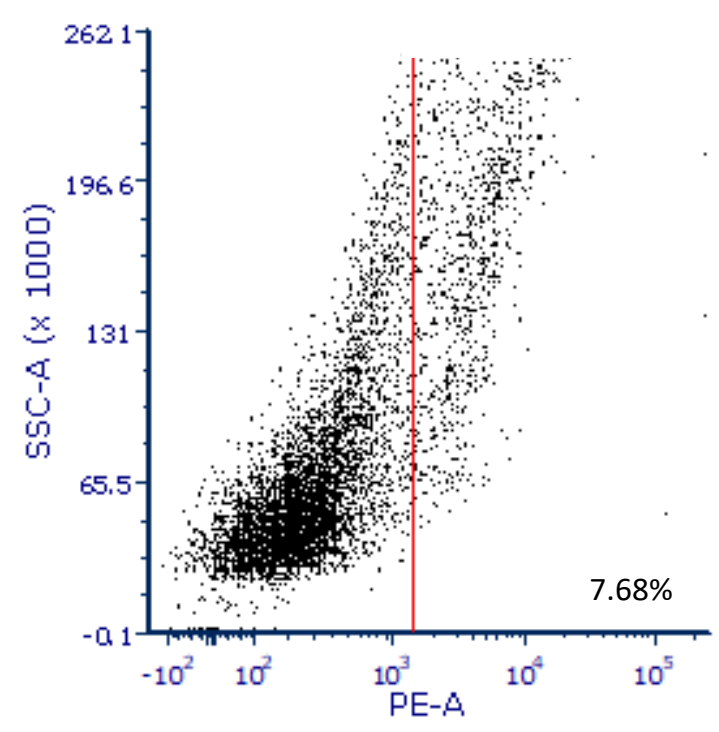

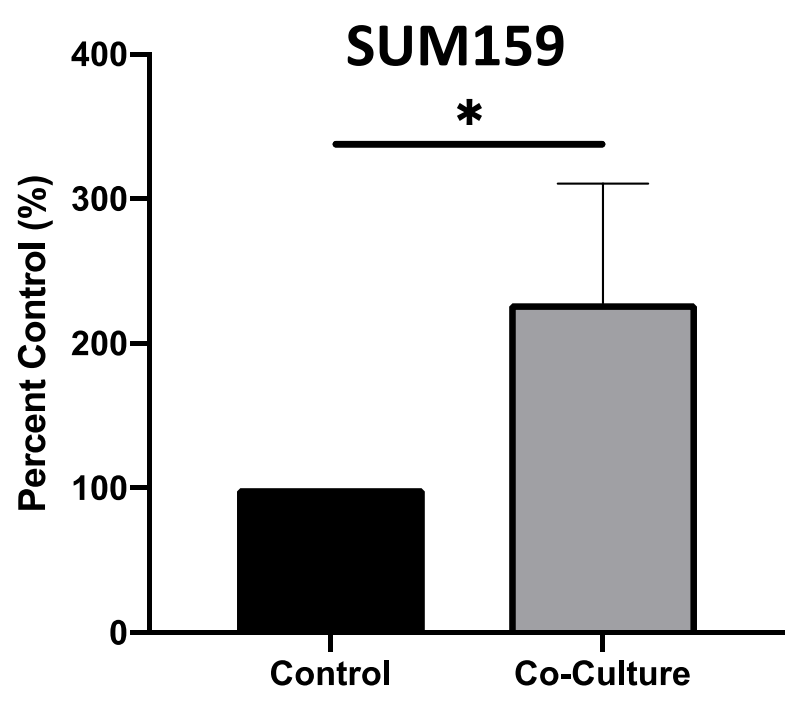




\section{Figure $2 b$}

Control
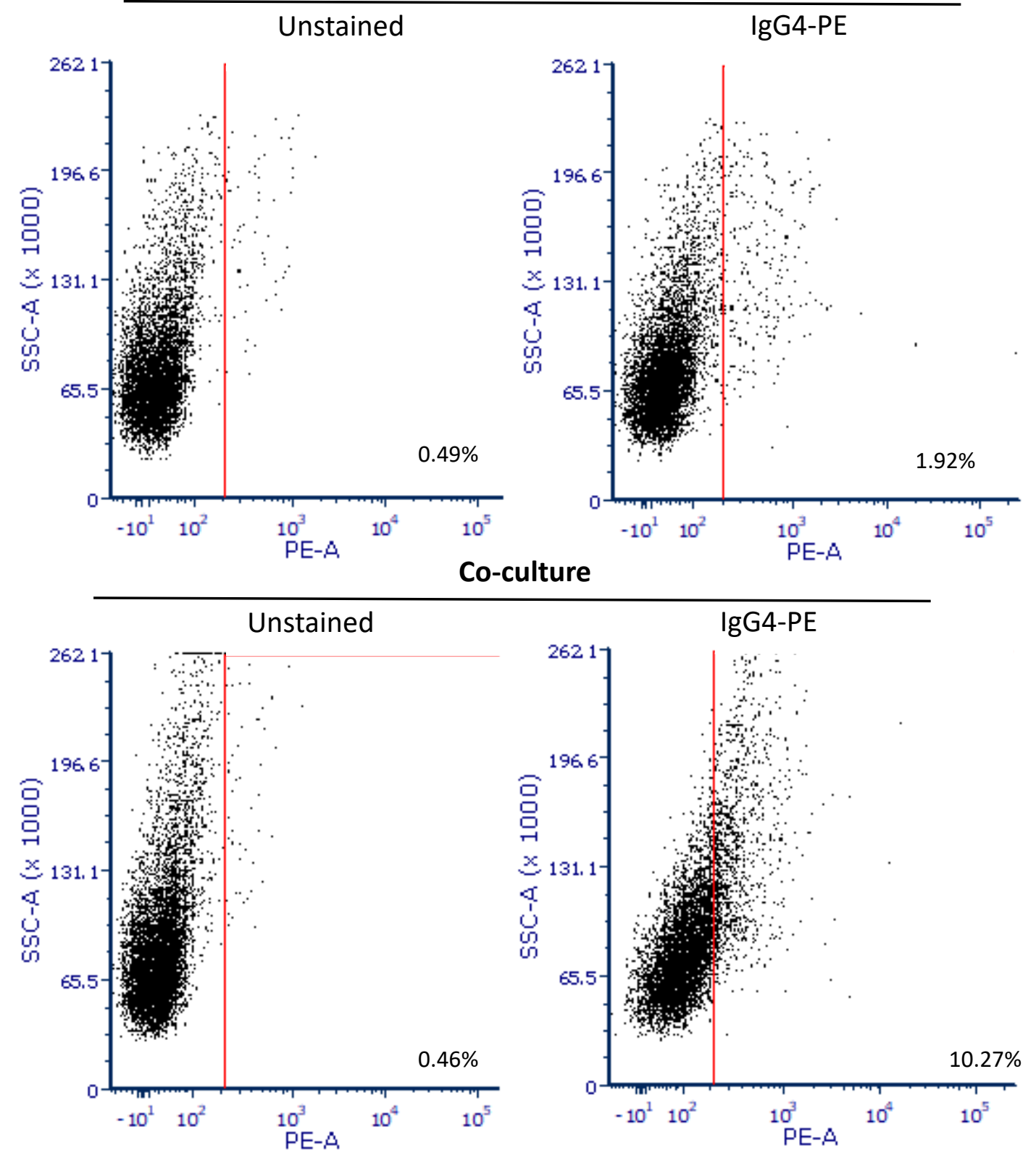

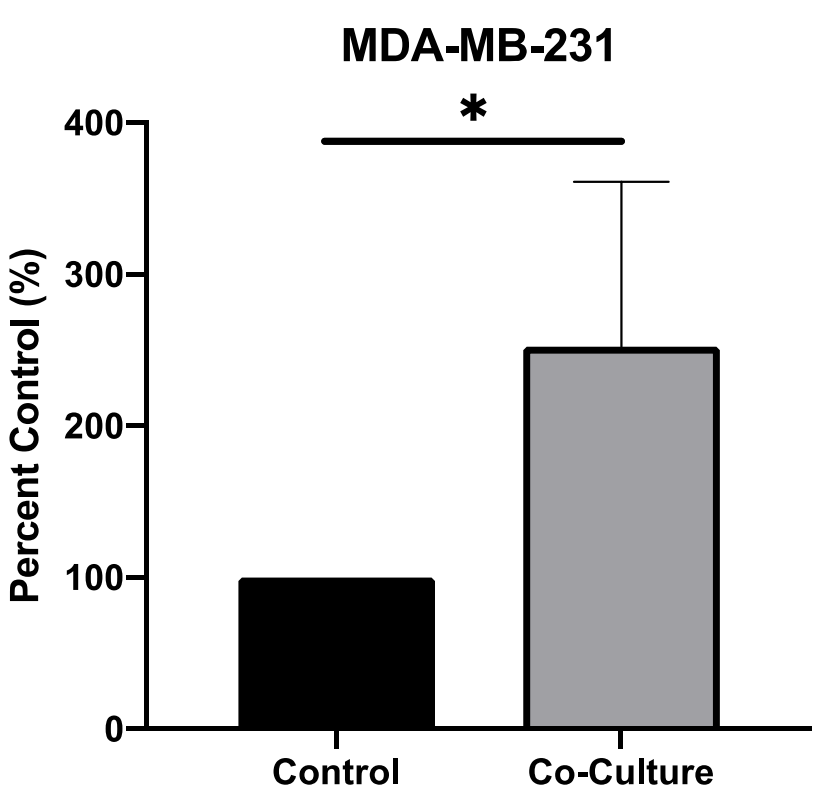



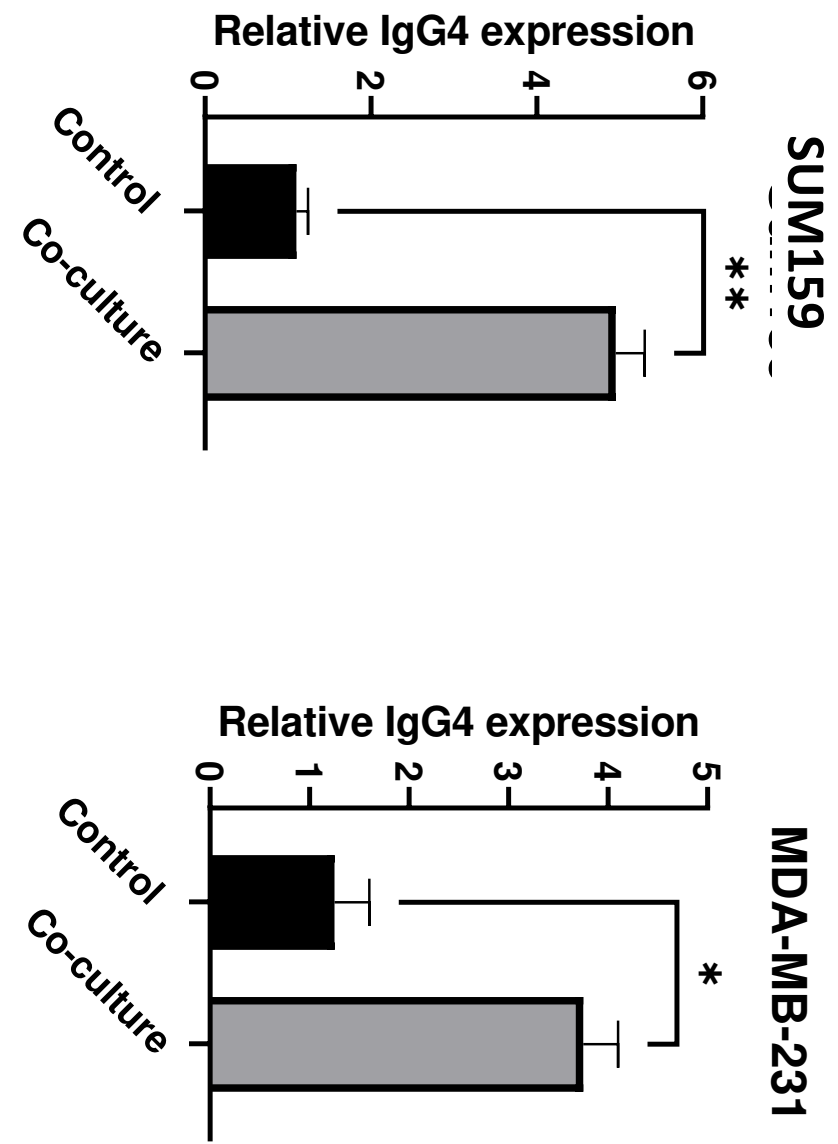


\section{Figure $2 \mathrm{e}$}
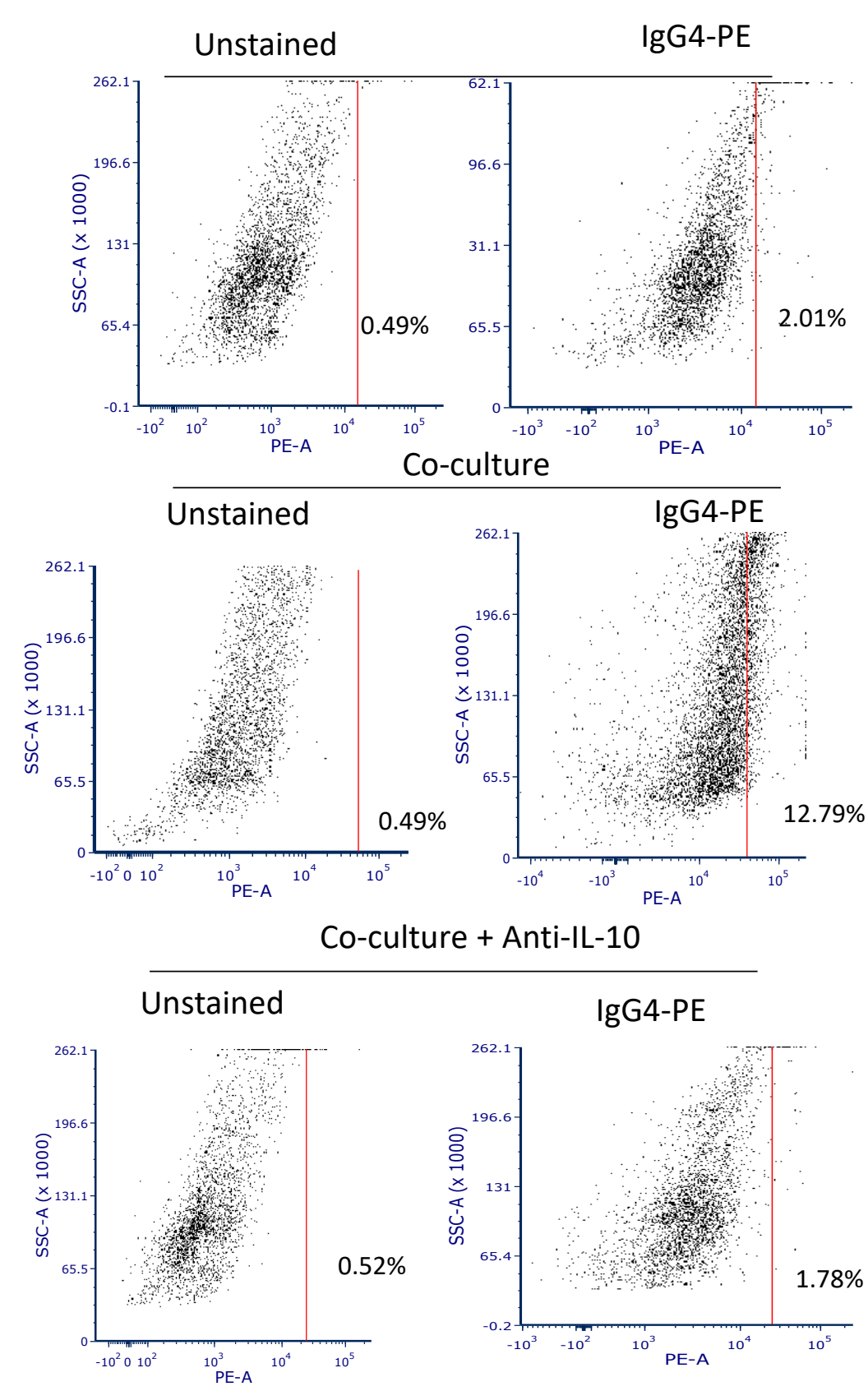

\section{MDA-MB-231}

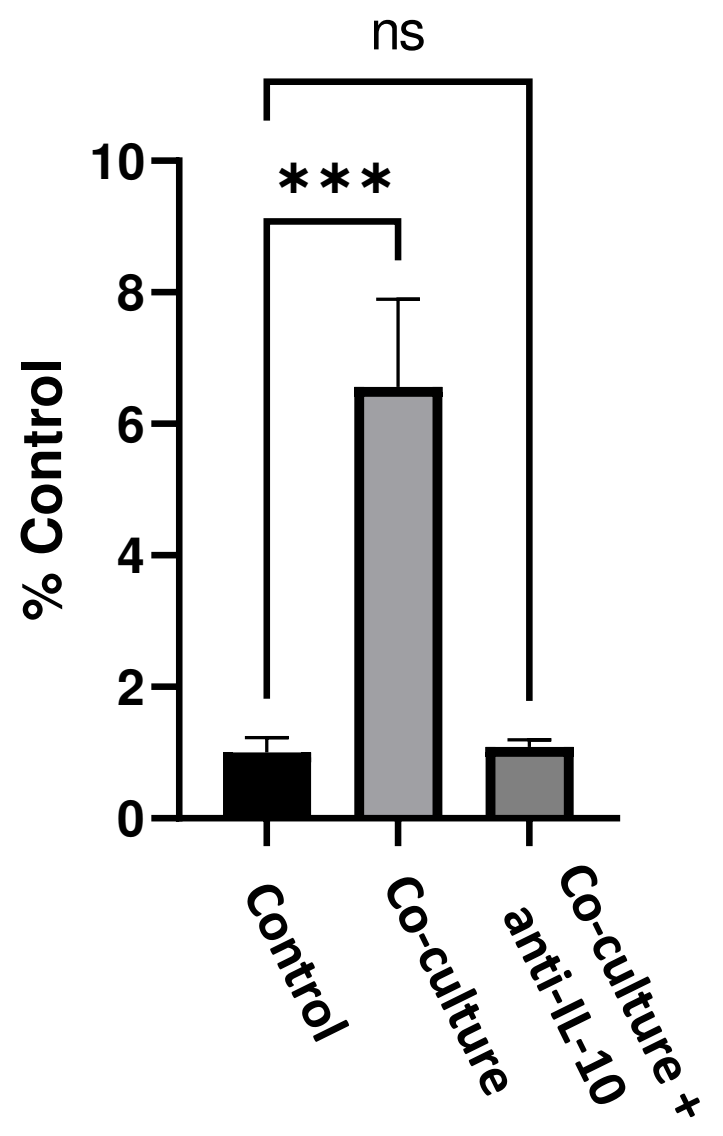




\section{Table 2}

\begin{tabular}{|c|c|c|c|}
\hline \multirow[t]{5}{*}{ Race } & \multicolumn{2}{|c|}{ Number } & \multirow{2}{*}{$\begin{array}{l}\text { Percent } \\
53.95\end{array}$} \\
\hline & White & 82 & \\
\hline & Black & 48 & 31.58 \\
\hline & Other & 1 & 0.06 \\
\hline & Unknown & 21 & 13.81 \\
\hline \multirow[t]{5}{*}{ Grade } & \multicolumn{2}{|c|}{ Number } & Percent \\
\hline & 1 & 2 & 1.98 \\
\hline & 2 & 26 & 17.11 \\
\hline & 3 & 116 & 76.31 \\
\hline & unknown & 8 & 5.26 \\
\hline \multirow[t]{9}{*}{ Stage } & \multicolumn{2}{|c|}{ Number } & Percent \\
\hline & 1 & 42 & 27.63 \\
\hline & $2 \mathrm{~A}$ & 17 & 11.18 \\
\hline & $2 b$ & 31 & 20.39 \\
\hline & $3 \mathrm{~A}$ & 21 & 13.8 \\
\hline & $3 B$ & 15 & 0.98 \\
\hline & $3 C$ & 9 & 5.92 \\
\hline & 4 & 2 & 1.31 \\
\hline & Unknown & 15 & 9.86 \\
\hline \multirow[t]{2}{*}{ Age } & \multicolumn{2}{|c|}{ Mean } & Range \\
\hline & & 62 & $32-93$ \\
\hline
\end{tabular}


Figure 3

\section{CD20}

$\lg G 4$

IL-10

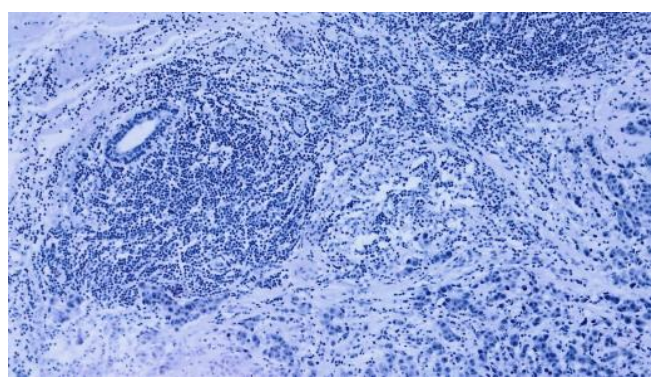

P2
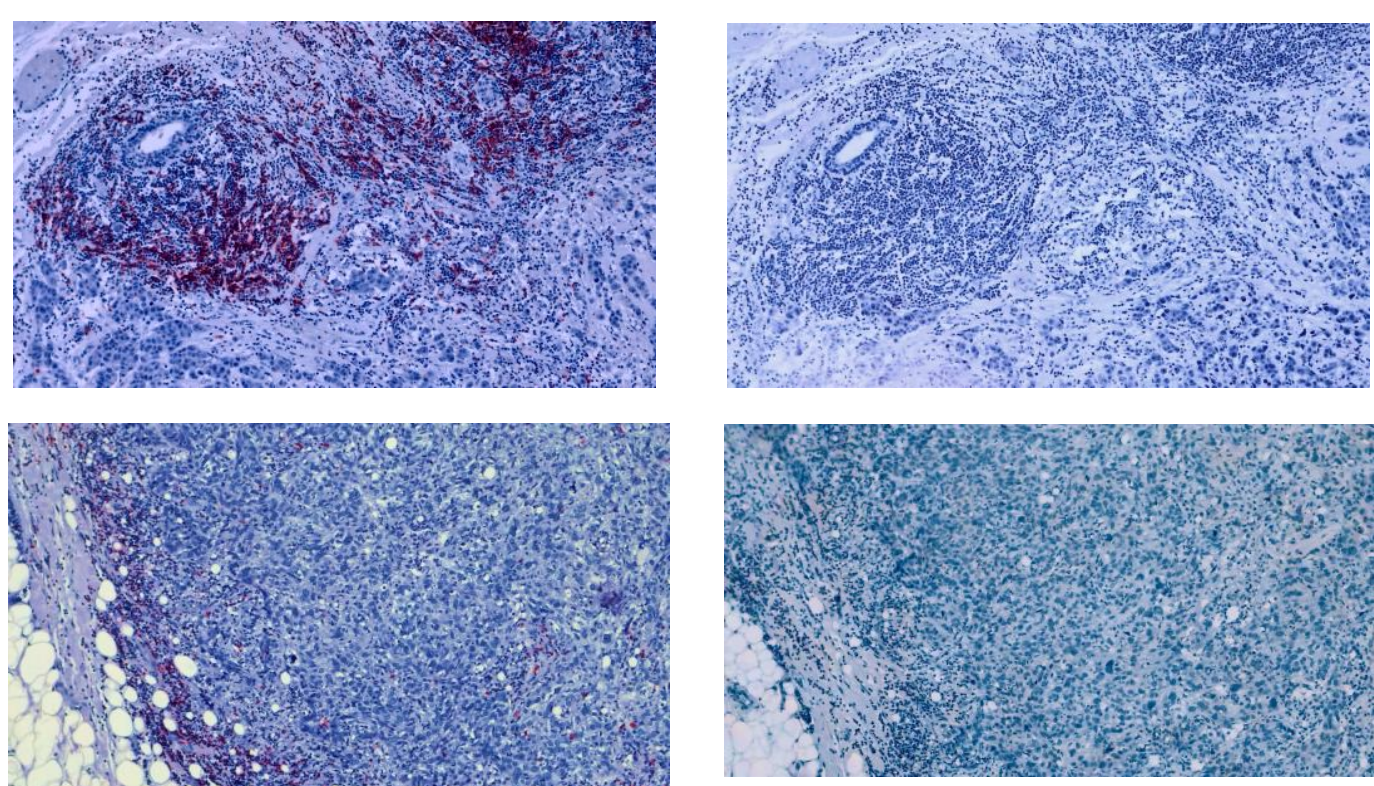

P3
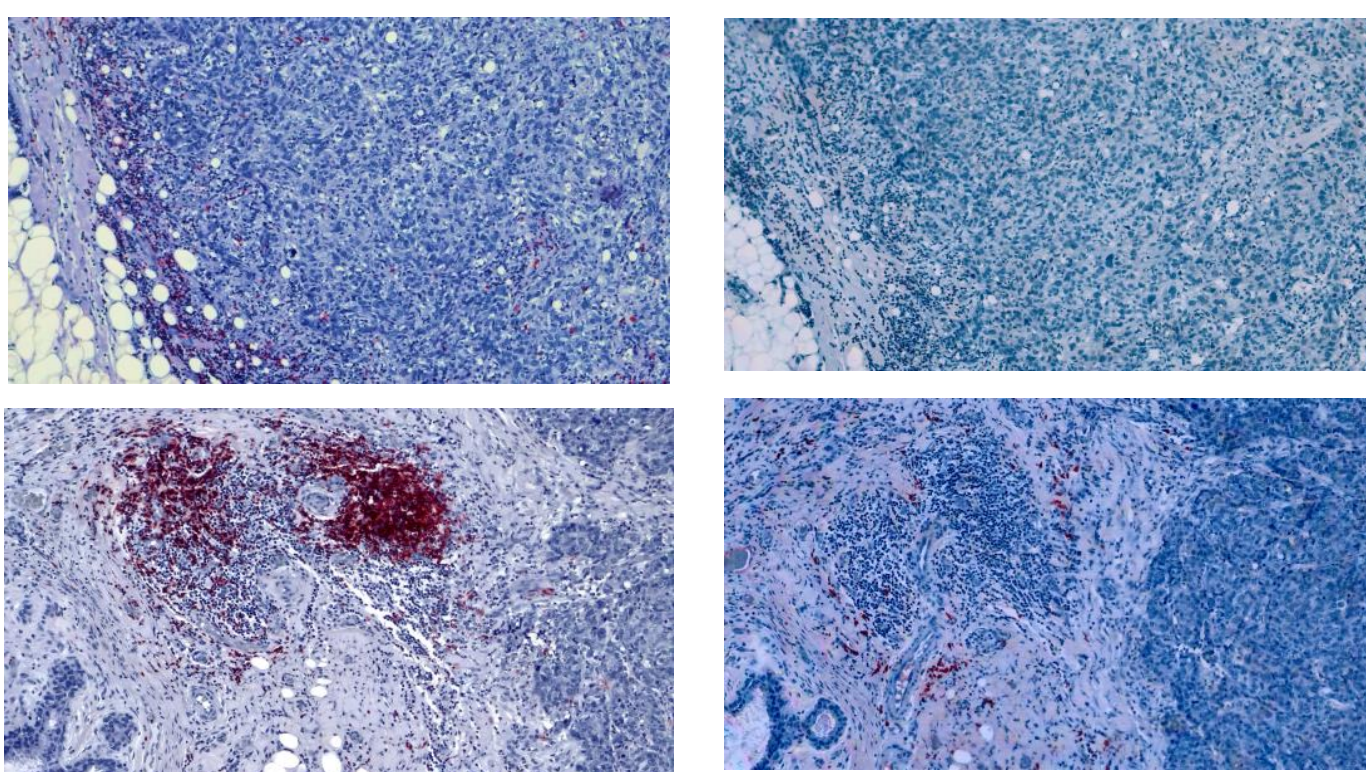

P4
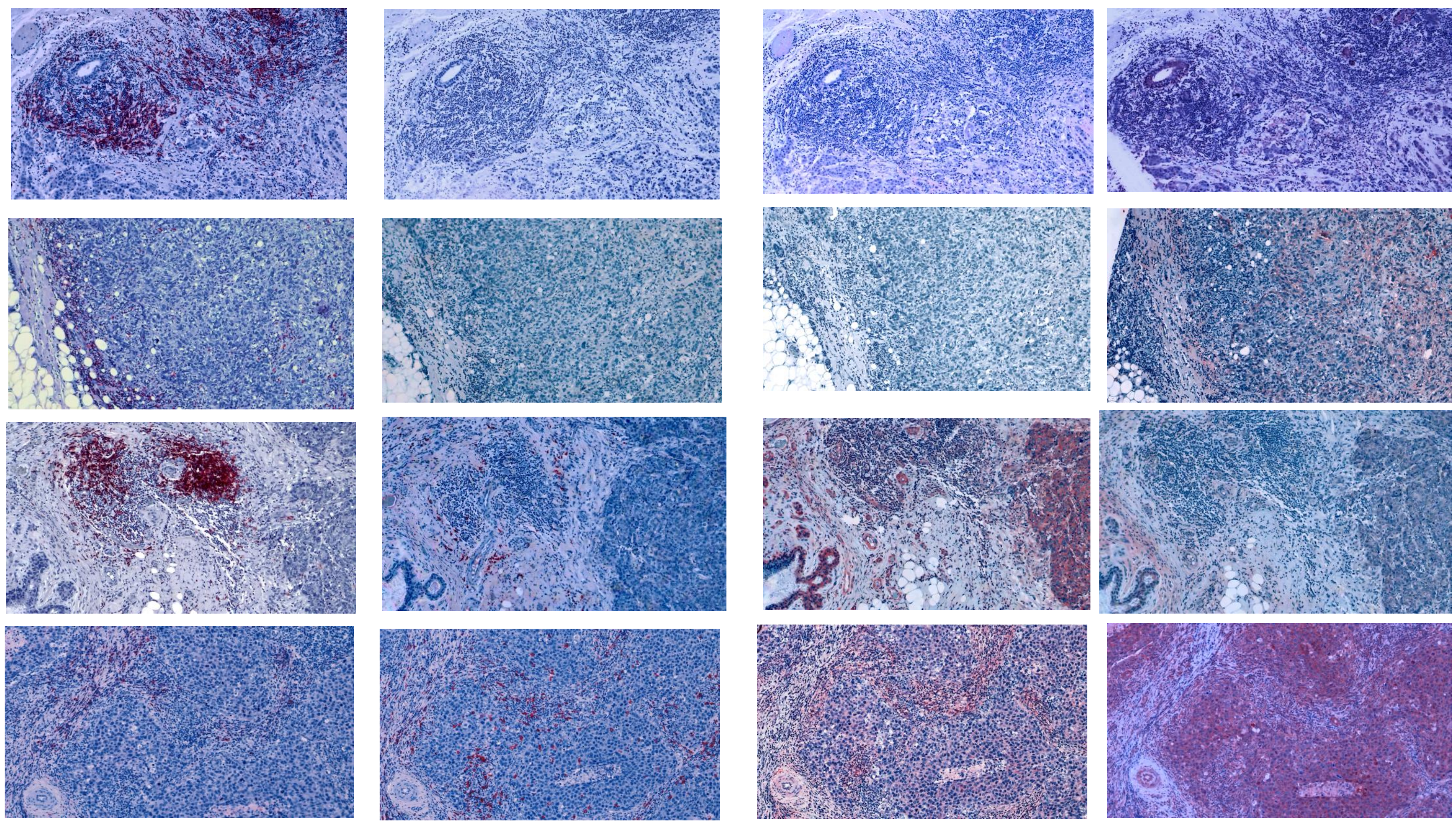
Figure 4

\section{CD20 Score}

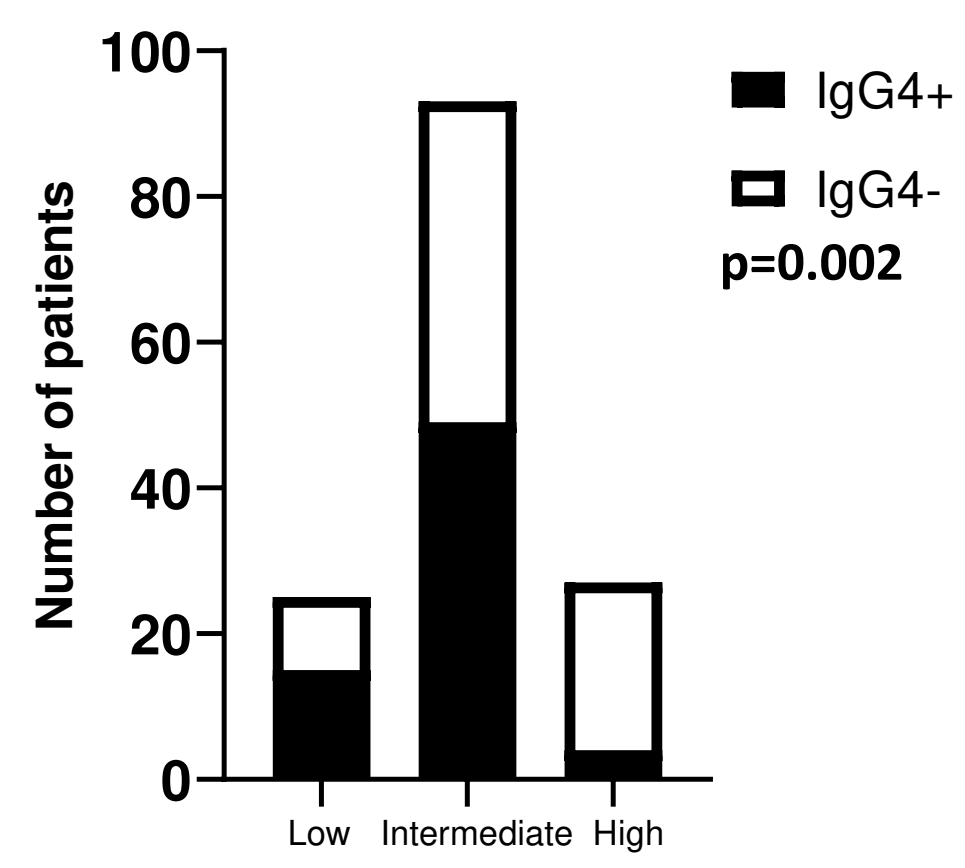


Table 3: Correlation Matrix

\begin{tabular}{|c|c|c|c|c|c|c|c|c|c|}
\hline & & Age & Race & Grade & Stage & \begin{tabular}{|l} 
CD20 \\
Score \\
\end{tabular} & $\begin{array}{l}\text { IgG4 } \\
\text { Score }\end{array}$ & $\begin{array}{l}\text { IL-10 } \\
\text { Score }\end{array}$ & $\begin{array}{c}\text { IL-4 } \\
\text { Score }\end{array}$ \\
\hline \multirow{2}{*}{ Age } & Spearman's r & 1 & $\stackrel{-}{-295^{\star \star}}$ & 0.048 & -0.001 & $\mid-0.169$ & -0.086 & 0.033 & -0.017 \\
\hline & Sig. (2-tailed) & & 0.001 & 0.588 & 0.995 & 0.055 & 0.328 & 0.712 & 0.853 \\
\hline \multirow{2}{*}{ Race } & Spearman's r & $-^{-} \cdot 5^{\star *}$ & 1 & 0.109 & $.234^{\star \star}$ & 0.015 & -0.058 & $-0.176^{\star}$ & 0.066 \\
\hline & Sig. (2-tailed) & 0.001 & & 0.184 & 0.007 & 0.857 & 0.481 & 0.031 & 0.432 \\
\hline \multirow{2}{*}{ Grade } & Spearman's r & 0.048 & 0.109 & 1 & 0.155 & 0.031 & 0.081 & 0.113 & -0.025 \\
\hline & Sig. (2-tailed) & 0.588 & 0.184 & & 0.075 & 0.705 & 0.327 & 0.171 & 0.762 \\
\hline \multirow{2}{*}{ Stage } & Spearman's $r$ & -0.001 & $.234^{\star \star}$ & 0.155 & 1 & $-.199^{\star}$ & 0.05 & $0.254^{*}$ & 0.106 \\
\hline & Sig. (2-tailed) & 0.995 & 0.007 & 0.075 & & 0.021 & 0.567 & 0.016 & 0.233 \\
\hline \multirow{2}{*}{ CD20 Score } & Spearman's r & -0.169 & 0.015 & 0.031 & $-.199^{*}$ & 1 & $-.190^{\star}$ & $-0.201^{*}$ & -0.047 \\
\hline & Sig. (2-tailed) & 0.055 & 0.857 & 0.705 & 0.021 & & 0.020 & 0.013 & 0.575 \\
\hline \multirow{2}{*}{ IgG4 Score } & Spearman's $r$ & -0.086 & -0.058 & 0.081 & 0.05 & $-0.190^{\star}$ & 1 & $0.448^{\star \star}$ & $0.262^{\star \star}$ \\
\hline & Sig. (2-tailed) & 0.328 & 0.481 & 0.327 & 0.567 & 0.020 & & 0.000 & 0.001 \\
\hline \multirow{2}{*}{ IL-10 Score } & Spearman's r & 0.013 & $-.182^{*}$ & 0.005 & $0.254^{\star}$ & $-.202^{*}$ & $0.448^{\star *}$ & 1 & 0.310 \\
\hline & Sig. (2-tailed) & 0.888 & 0.026 & 0.953 & 0.016 & 0.013 & 0.000 & & 0.714 \\
\hline \multirow{2}{*}{ IL-4 Score } & Spearman's r & -0.027 & 0.070 & 0.057 & 0.105 & -0.046 & $0.262^{\star \star}$ & 0.031 & 1 \\
\hline & Sig. (2-tailed) & 0.766 & 0.401 & 0.496 & 0.239 & 0.579 & 0.001 & 0.714 & \\
\hline
\end{tabular}

**. Correlation is significant at the 0.01 level (2-tailed).

*. Correlation is significant at the 0.05 level (2-tailed). 


\section{Figure 5 a}
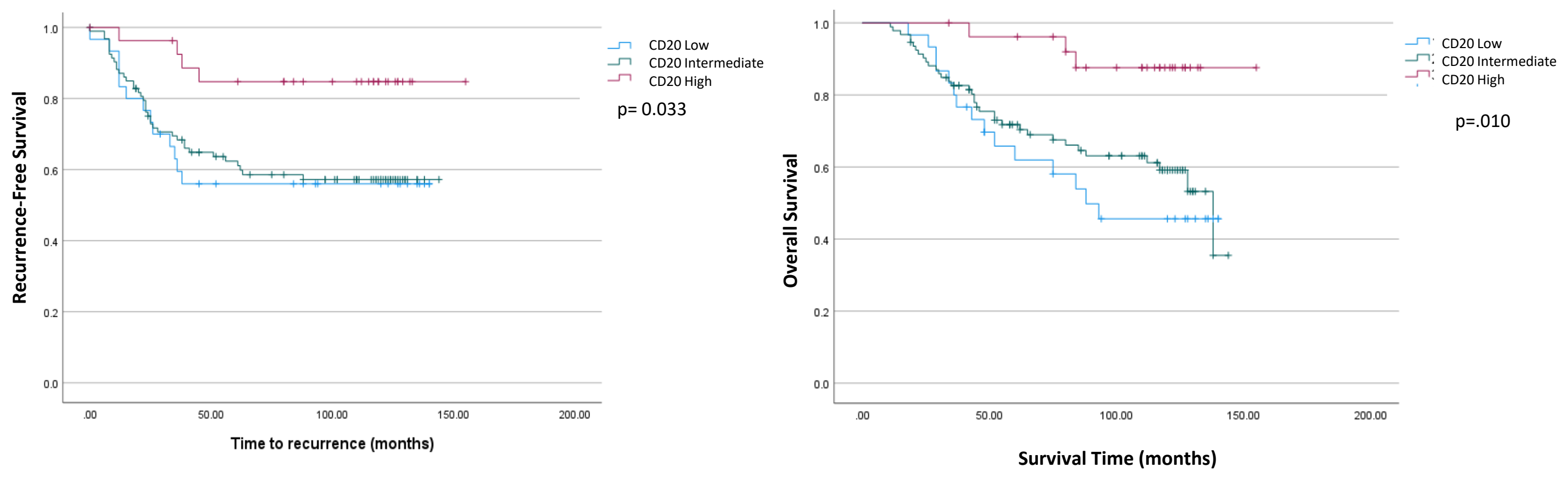


\section{Figure $5 b$}
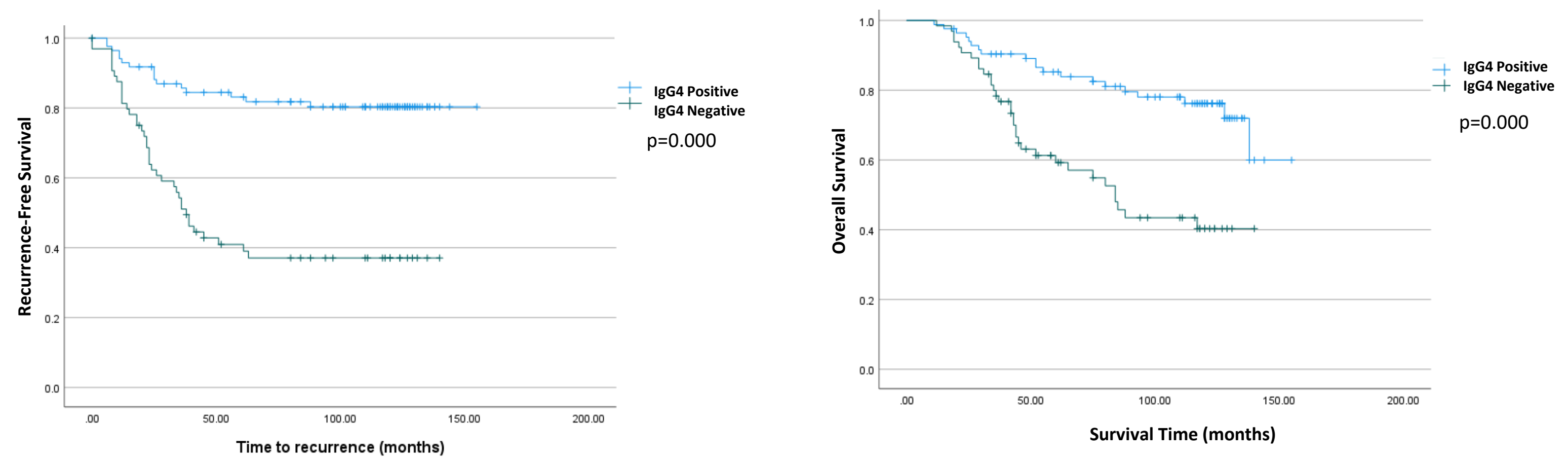


\section{Figure 5c}
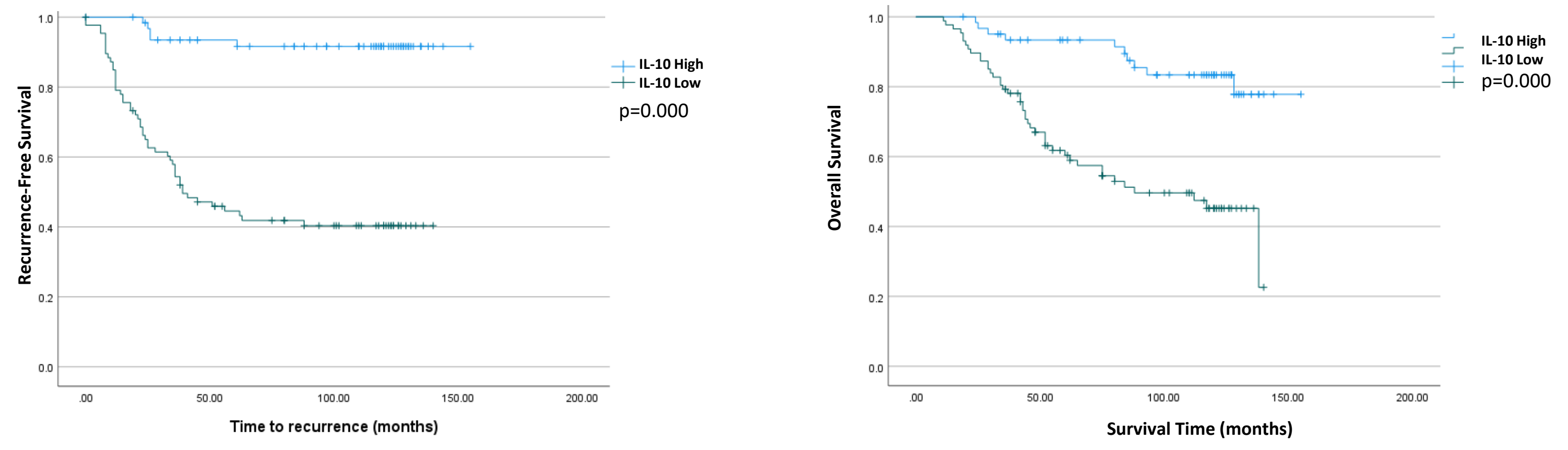


\section{Figure $5 d$}
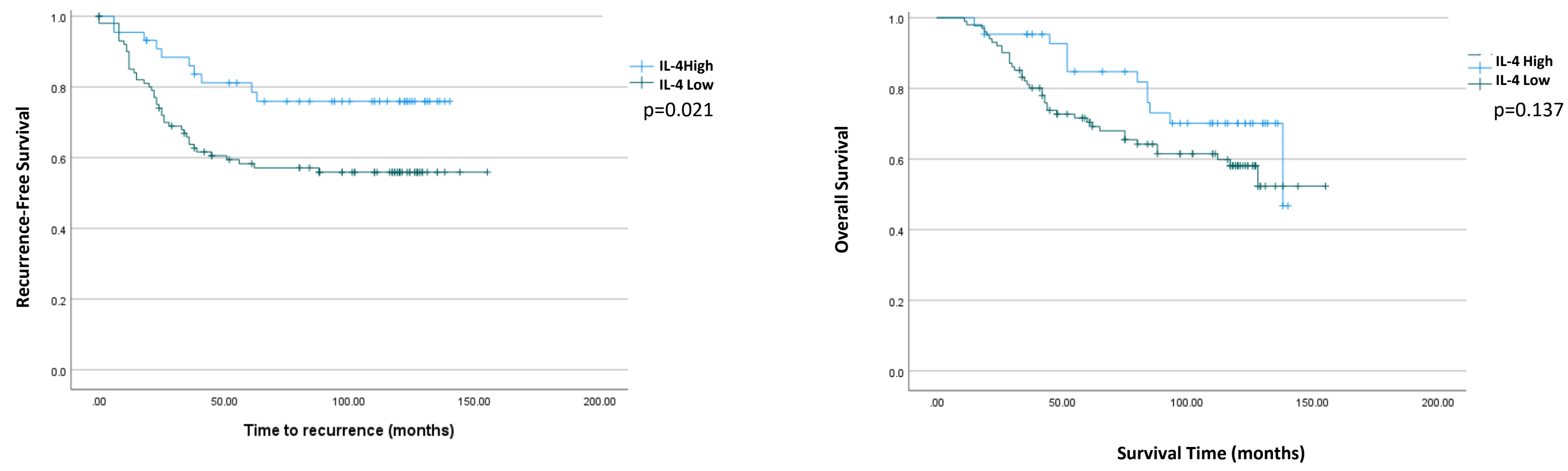
Table 4: Multivariate analysis

\begin{tabular}{|c|c|c|c|}
\hline \multicolumn{2}{|l|}{ Recurrence Free Survival } & \\
\hline & Sig & HR & $\mathbf{9 5 \%}$ Cl for HR \\
\hline Race & 0.791 & 1.095 & $0.560-2.140$ \\
\hline Grade & 0.34 & 1.128 & $0.881-1.445$ \\
\hline Stage & $\mathbf{0 . 0 0 0}$ & 1.442 & $1.247-1.667$ \\
\hline CD20 score & 0.231 & 0.72 & $00420-1.236$ \\
\hline IgG4 & $\mathbf{0 . 0 0 1}$ & 3.336 & $1.607-7.0560$ \\
\hline IL-10 & $\mathbf{0 . 0 0 0}$ & 7.195 & $2.418-21.411$ \\
\hline IL-4 & 0.279 & 1.535 & $0.707-3.337$ \\
\hline Overal Survival & & & \\
\hline & Sig & HR & $\mathbf{9 5 \%}$ Cl for HR \\
\hline Race & 0.604 & 0.83 & $0.411-1.678$ \\
\hline Grade & 0.931 & 1.014 & $0.736-1.398$ \\
\hline Stage & $\mathbf{0 . 0 0 0}$ & 1.329 & $1.151-1.534$ \\
\hline CD20 score & 0.211 & 0.706 & $0.409-1.218$ \\
\hline IgG4 & 0.074 & 2.541 & $1.204-5.336$ \\
\hline IL-10 & $\mathbf{0 . 0 0 5}$ & 4.101 & $1.538-10.934$ \\
\hline IL-4 & 0.528 & 1.283 & $0.592-2.779$ \\
\hline
\end{tabular}

